\title{
Evaluation of Low-E Storm Windows in the PNNL Lab Homes
}

JR Knox

SH Widder

May 2014

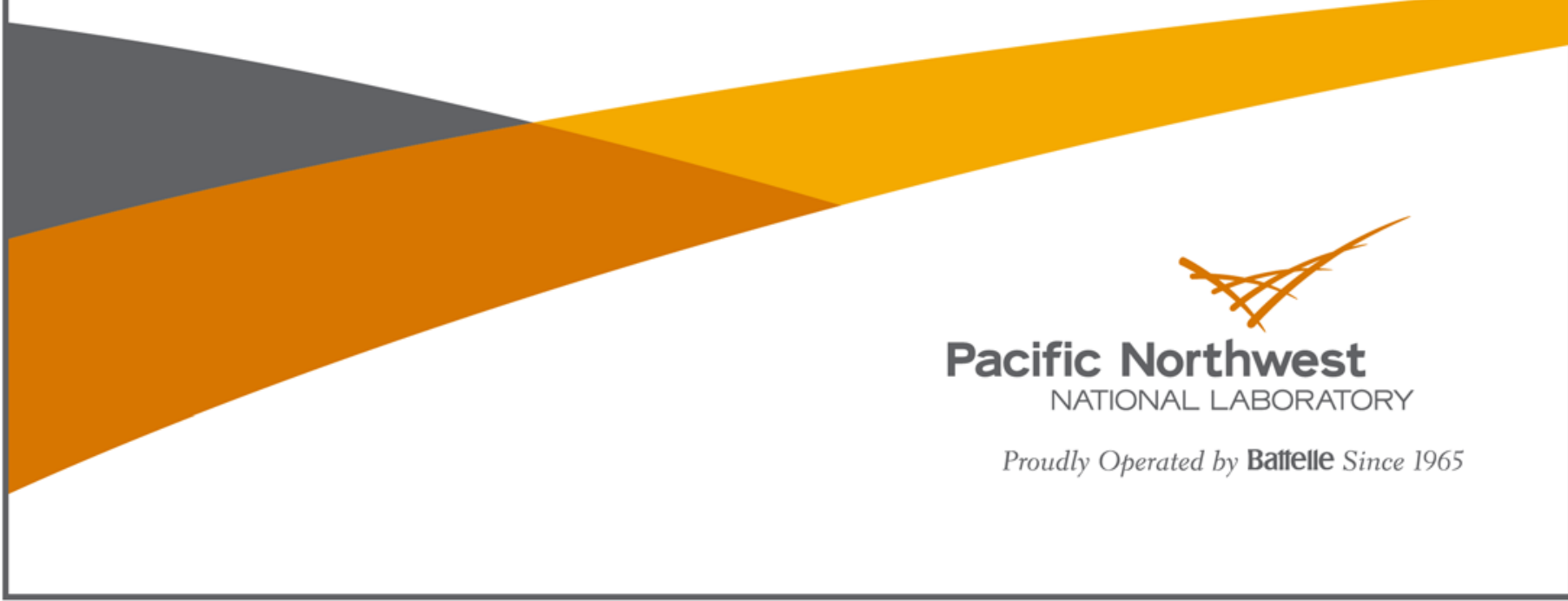




\title{
DISCLAIMER
}

This report was prepared as an account of work sponsored by an agency of the United States Government. Neither the United States Government nor any agency thereof, nor Battelle Memorial Institute, nor any of their employees, makes any warranty, express or implied, or assumes any legal liability or responsibility for the accuracy, completeness, or usefulness of any information, apparatus, product, or process disclosed, or represents that its use would not infringe privately owned rights. Reference herein to any specific commercial product, process, or service by trade name, trademark, manufacturer, or otherwise does not necessarily constitute or imply its endorsement, recommendation, or favoring by the United States Government or any agency thereof, or Battelle Memorial Institute. The views and opinions of authors expressed herein do not necessarily state or reflect those of the United States Government or any agency thereof.

\author{
PACIFIC NORTHWEST NATIONAL LABORATORY \\ operated by \\ BATTELLE \\ for the \\ UNITED STATES DEPARTMENT OF ENERGY \\ under Contract DE-AC05-76RL01830 \\ Printed in the United States of America \\ Available to DOE and DOE contractors from the \\ Office of Scientific and Technical Information, \\ P.O. Box 62, Oak Ridge, TN 37831-0062; \\ ph: (865) 576-8401 \\ fax: (865) 576-5728 \\ email: reports $a$ adonis.osti.gov \\ Available to the public from the National Technical Information Service \\ 5301 Shawnee Rd., Alexandria, VA 22312 \\ ph: (800) 553-NTIS (6847) \\ email: orders/antis.gov <http://www.ntis.gov/about/form.aspx> \\ Online ordering: http://www.ntis.gov
}




\section{Evaluation of Low-E Storm Windows in the PNNL Lab Homes}

JR Knox

SH Widder

May 2014

Prepared for

the U.S. Department of Energy

under Contract DE-AC05-76RL01830

Pacific Northwest National Laboratory

Richland, Washington 99352 



\section{Summary}

To examine the energy, air-leakage, and thermal-comfort performance of low-e storm windows, a field evaluation was undertaken in a matched pair of all-electric, factory-built "Lab Homes" located on the Pacific Northwest National Laboratory (PNNL) campus in Richland, Washington. The 1500 squarefoot homes are identical in construction and performance, which allows any difference in energy and thermal performance in the Experimental Home (Lab Home B) to be attributed to the retrofit technology installed.

To assess the performance of low-e storm windows in a residential retrofit application, the building shell air leakage, energy use, and interior temperatures of each home were compared during the 2013 summer cooling and 2014 winter heating seasons. Exterior low-e storm windows were installed over double-pane clear-glass, aluminum-frame primary windows in Lab Home B and were compared to the performance of the same double-pane clear-glass, aluminum-frame primary windows with no modifications in Lab Home A (the baseline home). The results of the experiment confirm the hypothesis that low-e storm windows reduce heating and cooling loads in the home when installed over primary windows. The measured energy savings in Lab Home B averaged 10.5\% for the heating season and 8.0\% for the cooling season for identical occupancy conditions. Extrapolating these energy savings numbers based on typical average heating degree days and cooling degree days per year yields an estimated annual energy savings of $10.1 \%$, or 2,216 $\mathrm{kWh} / \mathrm{yr}$ in the Experimental Home. Based on these savings and the estimated cost of the low-e storm windows provided by the manufacturer, the simple payback period was calculated to be between 5 and 7 years.

The low-e storm windows are expected to affect whole-house and heating, ventilation, and air conditioning energy use by:

1. reducing conductive heat transfer due to the insulating capabilities of the low-e storm window

2. reducing convective heat transfer due to the extra glass layer and airspace, as well as improved air-tightness around the window openings

3. reducing radiative energy losses due to the low emissivity coating

4. reducing solar gains due to a slightly lower solar heat gain coefficient (SHGC).

Reduced solar gains will increase savings in the summer and decrease savings in the winter, as not as much solar heat is available to contribute to space heating during the daytime. The low-e storm windows evaluated in this study are characterized as having relatively high SHGCs; thus, there is limited impact on solar gains through the window. This type of glass is ideal for northern climates. The test results suggest that the energy savings were primarily realized due to the decreased U-factor through the window, with no significant changes observed in infiltration. The low-e storm windows did not significantly decrease the air leakage of the home due to the air-tightness of the baseline primary window (i.e., the primary windows are already well-sealed). For homes with "leakier" older windows, the storm windows would likely generate more savings than observed in this study.

The thermal-comfort impact of low-e storm windows was evaluated as part of this experiment using the mean radiant temperature (MRT) measurement, which measures the radiant heat exchange between an occupant (a body) and surrounding surface temperatures such as the surface temperature of a window or a 
wall. A comparison of MRT between the homes suggests a potentially higher comfort level for occupants with the use of low-e storm windows.

Low-e storm windows are available in both exterior and interior window attachments. To compare the evaluated performance of exterior low-e storm windows to similar interior products, a preliminary evaluation of interior low-e storm windows was completed in the 2014 heating season. This preliminary evaluation suggests similar performance of the interior and exterior low-e storm windows in terms of energy savings, but further testing is needed to accurately measure the savings generated by interior low-e storm windows and more fully document their air-leakage and thermal-comfort impacts.

This whole home experimental field evaluation has added to the body of knowledge surrounding lowe storm window performance by accurately measuring the energy savings and thermal comfort impacts of low-e storm windows in a controlled setting. Additional studies are needed to fully document the performance of low-e storm windows across a variety of building types and climate zones and determine the cost effectiveness of low-e storm windows in a variety of retrofit scenarios; however, the data clearly demonstrate that low-e storm windows can be an effective energy-saving measure that should be considered for retrofits in residential homes. The energy savings from retrofitting double-pane, clearglass windows with low-e storm windows was found to be similar to savings that resulted from the replacement of the double-pane, clear-glass windows with new triple-pane primary windows. 


\section{Acknowledgments}

The authors would like to thank Tom Culp of Birch Point Consulting who assisted in the preparation of this document by providing input, comments, and suggestions.

The authors would also like to thank Larson Manufacturing Company and Quanta Technologies for providing low-e storm windows for the Lab Home experiments. We also acknowledge the technical assistance provided by Todd Stratmoen of Larson Manufacturing Company during the installation of the exterior storm windows on the Experimental Home. 



\section{Acronyms and Abbreviations}

$\mathrm{ACH} 50$

BTP

Btu

CDD

$\mathrm{cfm}$

cfm50

$\mathrm{CU}$

d

DOE

ET

${ }^{\circ} \mathrm{F}$

$\mathrm{ft}$

HDD

hr

HVAC

$\mathrm{kW}$

kWh

LBNL

low-e

MRT

NAHB

NEAT

NFRC

$\mathrm{Pa}$

RECS

RESFEN

SEER

SHGC

WAP

Wh

$\mathrm{W} / \mathrm{m}^{2}$

$\mathrm{yr}$ air changes per hour at 50 Pascals of depressurization with respect to the outside Building Technologies Program

British thermal unit

cooling degree days

cubic feet per minute

cubic feet per minute at 50 Pascals of depressurization with respect to outside condensing unit

day(s)

U.S. Department of Energy

Emerging Technologies

Fahrenheit

foot (feet)

heating degree days

hour(s)

heating, ventilation, and air-conditioning

kilowatt(s)

kilowatt hour

Lawrence Berkeley National Laboratory

low-emissivity

meant radiant temperature

National Association of Home Builders

National Energy Audit Tool

National Fenestration Rating Council

Pascal(s)

Renewable Energy Consumption Survey

RESidential FENestration

seasonal energy-efficiency ratio

solar heat gain coefficient

Weatherization Assistance Program

watt-hour(s)

watts per square meter

year(s) 



\section{Contents}

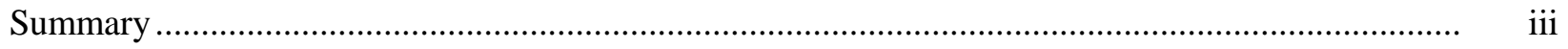

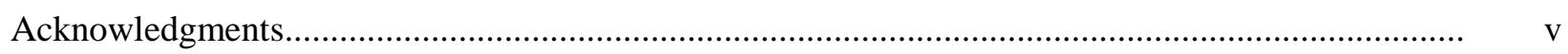

Acronyms and Abbreviations .......................................................................................................... vii

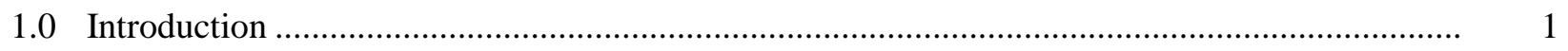

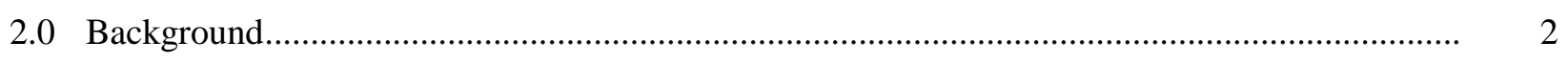

2.1 Low-E Storm Windows Technology ............................................................................ 2

2.2 Low-E Storm Windows Development and Previous Research........................................ 2

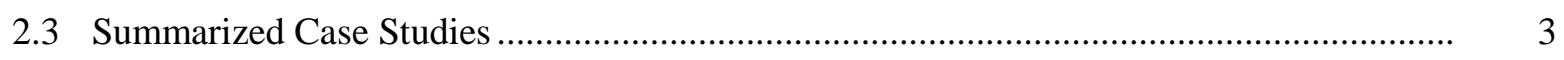

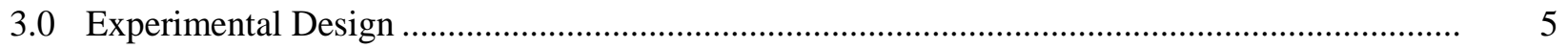

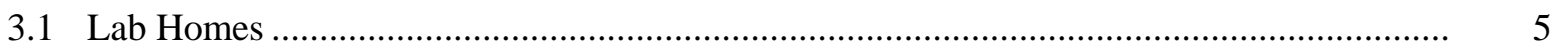

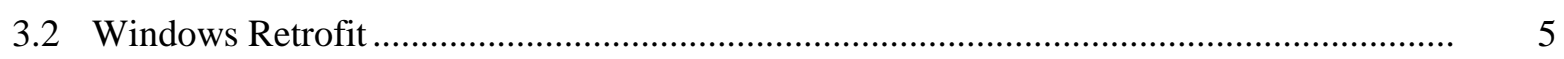

3.2.1 Exterior Low-E Storm Window Performance Ratings............................................ 7

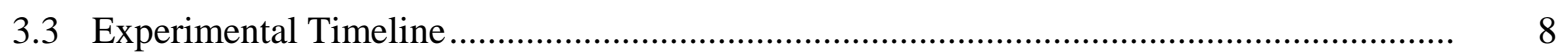

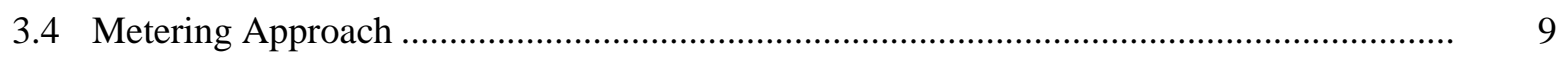

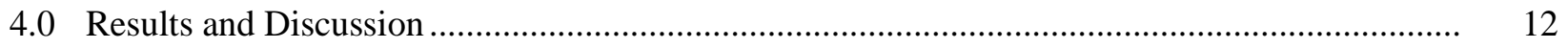

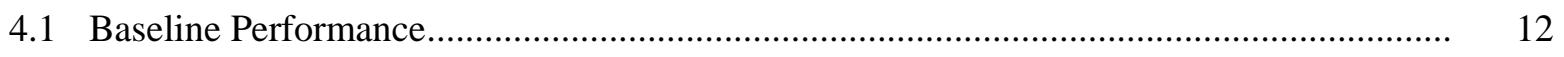

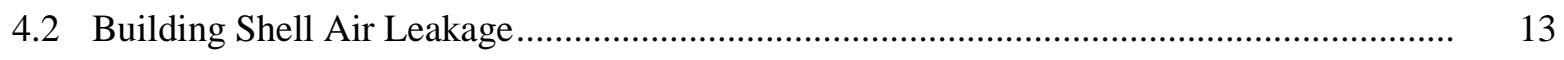

4.3 Low-E Storm Window Energy Performance ................................................................... 15

4.3.1 Summer Cooling Season Results …................................................................... 16

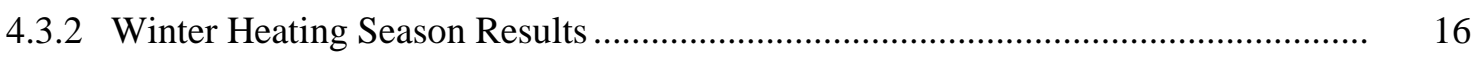

4.3.3 Dependence on Outdoor Air Temperature and Solar Insolation ............................. 18

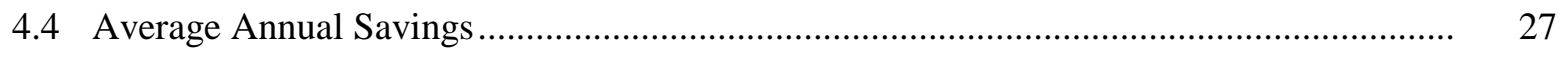

4.5 Cost Effectiveness of Exterior Low-E Storm Windows ................................................. 27

4.6 Interior Temperature Distributions................................................................................. 28

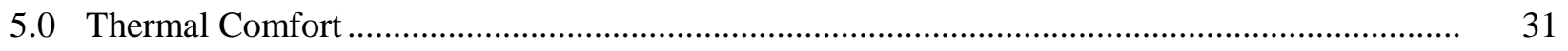

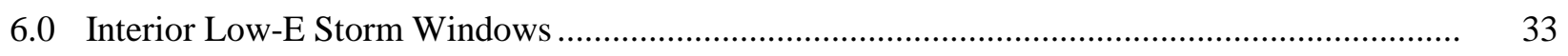

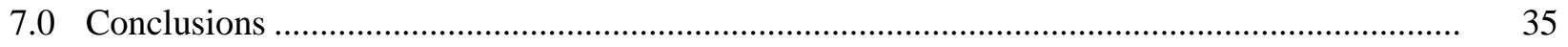

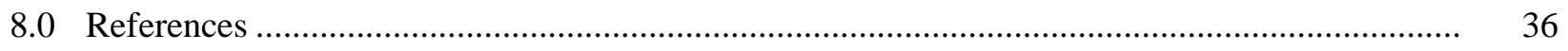

Appendix A - Installation Process for Low-E Exterior Storm Windows ......................................... A.1

Appendix B - Installation Process for Low-E Interior Storm Windows ........................................... B. B.1 



\section{Figures}

3.1 Floor Plan of the Lab Homes as Constructed..................................................................... 5

3.2 Mounting Surface for Exterior Storm Windows in Lab Homes B .......................................... 7

4.1 Cumulative Energy Use of Lab Home B (Experimental Home) Versus Lab Home A (Baseline Home) during Baselining of the Homes.

4.2 Whole-House Energy Use (Wh/d; left axis) and Whole-House Energy Savings (\%; right axis) Versus Outdoor Air Temperature $\left({ }^{\circ} \mathrm{F}\right)$

4.3 Whole-House Energy Use and Indoor Temperature for the Experimental Home (blue and green lines) and the Baseline Home (red and purple lines) on a Cold, Sunny Day

4.4 Cumulative Energy Use of Lab Home B (Experimental Home) Versus Lab Home A (Baseline Home) on a Cold, Sunny Day.

4.5 Whole-House Energy Use and Indoor Temperature for the Experimental Home (blue and green lines) and the Baseline Home (red and purple lines) on a Cold and Cloudy Day

4.6 Cumulative Energy Use of Lab Home B (Experimental Home) Versus Lab Home A (Baseline Home) on a Cold and Cloudy Day.

4.7 Solar Insolation through West-Facing Window during the Heating Season

4.8 Cumulative Energy Use of Lab Home B (Experimental Home) Versus Lab Home a (Baseline Home) on a Hot Day.

4.9 Cumulative Energy Use of Lab Home B (Experimental Home) Versus Lab Home A (Baseline Home) on a Hot Day.

4.10 Cumulative Energy Use of Lab Home B (Experimental Home) Versus Lab Home A (Baseline Home) on a Milder Day (daily average outdoor air temperature of $65^{\circ} \mathrm{F}$ )......

4.11 Hourly Average Whole-House Energy Use and Indoor Temperature for the Experimental Home (red and purple lines) and the Baseline Home (blue and green lines) and Outdoor Air Temperature on a Mild Day

4.12 Interior Temperature Distribution for Lab Home A (left) and Lab Home B (right) on a Sunny Day in the Heating Season

4.13 Interior Temperature Distribution for Lab Home A (left) and Lab Home B (right) on a Hot Sunny Day.

5.1 Daily Mean Radiant Temperature Profile of Lab Homes A and B (blue line and red line, respectively) in the Living Room (left) and Master Bedroom (right) during the Heating Season

5.2 Daily Mean Radiant Temperature Profile of Lab Homes A and B (blue line and red line, respectively) in the Living Room (left) and Master Bedroom (right) during the Cooling Season 


\section{Tables}

2.1 Summarized Case Studies Focused on Low-E Storm Windows..............................................

3.1 Primary Window Characteristics ................................................................................ 7

3.2 Experimental Timeline................................................................................................... 9

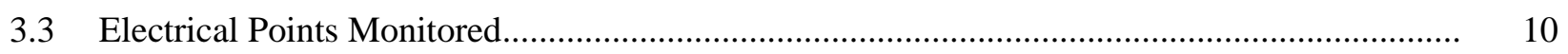

3.4 Temperature and Environmental Points Monitored ............................................................. 10

4.1 Blower Door Test Results Prior to Storm Windows Installation ............................................... 14

4.2 Blower Door Test Results after Exterior Storm Window Installation ....................................... 14

4.3 Average Daily Energy Savings and 95\% Confidence Interval from Low-E Storm Windows Without and With Blinds ............................................................................................... 16

4.4 Average Daily Energy Savings and 95\% Confidence Interval from Low-E Storm Windows

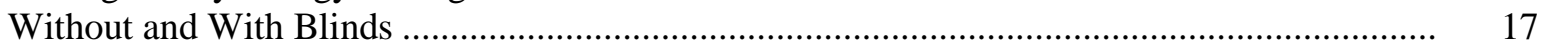

4.5 Annual Energy Savings Generated by Exterior Low-E Storm Windows ................................ 27

4.6 Cost-Effectiveness Calculations for Low-E- Storm Windows................................................. 28

6.1 Average Daily Energy Savings and 95\% Confidence Interval from Low-E Interior Storm Windows 


\subsection{Introduction}

Residential buildings in the United States currently require approximately 9.5 quadrillion Btus of energy for heating and cooling, which accounts for more than $40 \%$ of the primary energy consumed by homes. Windows are a major source of heating losses and gains in residential buildings because of their heat transfer and infiltration properties, especially relative to other building shell components. For example, it has been estimated that windows account for approximately $25 \%$ of the energy use in a typical residential building (Huang et al. 1999). It has been estimated that more than three quarters of U.S. residential homes are equipped with single-pane or double-pane clear-glass windows. The presence of single-pane and double-pane clear-glass windows in homes has persisted over the past two decades, despite the fact that approximately 30 million windows are replaced each year with higher performing, insulated windows. (AAMA 2012). ${ }^{1}$ While the window industry has made many advances in energy efficiency over the last decade, the installation of low-emissivity (low-e) double-pane windows has largely been limited to new housing and major remodeling projects in part because of the large expense of replacing windows.

Retrofitting and renovating existing homes to save energy has become an increasingly important component of the nation's energy strategy, and energy-efficient window attachments, such as low-e storm windows, can significantly improve the thermal performance of a window and be installed for a fraction of the cost of a full primary window replacement. New interior and exterior storm windows incorporating low-e glass offer a low-cost alternative to the replacement of primary windows.

This report describes whole home experimental research conducted in support of the Building America's Low-e Storm Window Adoption Program. The purpose of this project is to evaluate the energy savings potential of installing low-e storm windows over typical double-pane clear aluminumframe windows in the Pacific Northwest National Laboratory's (PNNL) matched pair of Lab Homes. ${ }^{2}$ The performance of the home's heating, ventilation, and air conditioning (HVAC) system (the thermal performance of the home) was measured and compared to the thermal performance of a home without low-e storm windows during heating and cooling season periods. Both homes deploy identical simulated occupancy schedules so that the performance and effects of the low-e storm windows will be isolated from all other variables. The results from the research, as presented in this report, help validate savings and performance of installing low-e storm windows over double-pane clear primary windows and help facilitate the integration of low-e storm windows into residential energy simulation models that support energy-efficiency retrofits. The U.S. Department of Energy's (DOE) Building America Program serves as a catalyst to accelerate the residential building energy-efficiency market transformation and support increasing levels of cost-effective whole-house energy savings.

\footnotetext{
${ }^{1}$ Single-pane estimates are from Renewable Energy Consumption Survey (RECS) 2009 (47.2 million homes or $\sim 40 \%$ ). Although the 2009 RECS did not include estimates of double-pane clear windows, the 2005 RECS estimated 50.6 million homes with double-pane clear windows (DOE-EIA 2005). The current estimate is based on estimates of prime window replacements (AAMA 2012) during the time frame and window trends between the 2005 and 2009 RECS. This corresponds with an estimate of 46 million homes, or nearly $40 \%$ of the residential homes.

${ }^{2}$ See http://labhomes.pnnl.gov for more information on Lab Homes.
} 


\subsection{Background}

Storm windows have been a technology option for improving the performance of existing windows for decades. Recently, advances in storm window technology have improved storm window designs to incorporate low-e coatings and a variety of operable designs, among other things, which increase the energy performance and utility of storm windows. Today's storm windows can be permanently installed in homes and case studies have demonstrated how they can save energy in residential homes in various regions throughout the U.S.

\subsection{Low-E Storm Windows Technology}

Traditional storm windows consisted of a single piece of clear glass (or plastic) in a wood or aluminum frame and were installed on the outside of an existing window. Modern storm windows can be operable or fixed in place and come in a variety of configurations and trim colors. They typically have insert screens to allow for natural ventilation, tighter seals for less air leakage, and are intended to be permanently mounted. Typical low-e storm windows look just like other modern storm windows but include a low-e pyrolytic coating that lowers the emissivity of glass, effectively reducing the heat transmission (i.e., increasing the R-value or insulation) through the storm window. The pyrolytic coat is a hard tin-oxide based ceramic coating deposited onto the glass during the float glass process ${ }^{1}$ that is durable and can withstand the elements, unlike soft-coat or sputtered low-e coatings that are more typical of primary windows and must be protected in a sealed double pane unit.

\subsection{Low-E Storm Windows Development and Previous Research}

Low-e coated glass was first developed to improve the energy performance of new and replacement windows to reduce heat loss through building enclosures. Subsequently in the 1990s, the DOE's Building Technologies Program (BTP) began exploring the concept of applying low-e coatings to storm windows. Development and laboratory testing efforts were primarily led by researchers at Lawrence Berkeley National Laboratory (LBNL) (Klems 2003). Early field testing at the Mobile Window Thermal Test (MoWiTT) facility demonstrated that these low-e storm windows, attached over an existing primary window, provided the same overall performance as installing new low-e double-pane primary windows. BTP's Emerging Technologies (ET) program continued supporting the development and field testing of low-e storm windows in collaboration with the National Association of Home Builders (NAHB) Research Center and Utilivate Technologies (Drumheller et al. 2007). The ET team also supported demonstrations of the technology with case studies and initiated deployment efforts by including low-e storm windows as part of its windows volume purchase market transformation program (Parker et al. 2013). ET continued to fund field case studies and educational programs (Quanta Technologies 2013), and initiated a pilot program to integrate low-e storm windows as a qualified weatherization measure in Pennsylvania as part of DOE’s Weatherization Assistance Program (WAP) (Krigger and Van der Meer 2011).

\footnotetext{
${ }^{1}$ The float glass process is how window glass is made. It involved floating molten silica, combined with soda lime and other elements, on a bed of molten tin and then cooling the glass in a controlled environment.
} 


\subsection{Summarized Case Studies}

A series of laboratory tests have proven that low-e storm windows save energy at the component level. The performance improvements have been validated with field tests and case studies supported by BTP's ET team. The approaches and results of these field tests and case studies are described and summarized in previous reports (Cort 2013) and a high-level summary of these activities is provided in Table 2.1.

In addition to case studies, a number of climate-based modeling efforts have been performed to examine the potential energy savings and the cost effectiveness of installing low-e storm windows over existing windows in residential homes across a broad range of U.S. climate zones. Calculations of energy savings and the cost effectiveness of low-e storm windows were conducted with two software platforms: the National Energy Audit Tool (NEAT), used by weatherization programs, and RESFEN (RESidential FENestration) software, used to compare the annual energy performance of different window options in single-family homes (Culp and Cort 2013).

Table 2.1. Summarized Case Studies Focused on Low-E Storm Windows

\begin{tabular}{|c|c|c|c|}
\hline Study & Sponsor & Baseline Description & Findings \\
\hline $\begin{array}{l}\text { Chicago Case Study } \\
\text { (2007) }\end{array}$ & $\begin{array}{l}\text { DOE, HUD, } \\
\text { NAHB } \\
\text { Research } \\
\text { Center, LBNL }\end{array}$ & $\begin{array}{l}6 \text { low-income homes; } \\
\text { single-pane wood } \\
\text { framed windows }\end{array}$ & $\begin{array}{l}\text { - } 21 \% \text { reduction in overall home heating load } \\
\text { - } 7 \% \text { reduction in overall home air infiltration } \\
\text { - } \text { Simple payback of } 4 \text { to } 5 \text { years }\end{array}$ \\
\hline $\begin{array}{l}\text { Infrared Camera } \\
\text { Imaging }\end{array}$ & $\begin{array}{l}\text { DOE, LBNL, } \\
\text { Building Green }\end{array}$ & $\begin{array}{l}\text { Single-pane wood } \\
\text { framed windows }\end{array}$ & $\begin{array}{l}\text { Images showed that interior low-e storm windows } \\
\text { performed equivalently or better than new double-pane } \\
\text { replacement windows with low-e glass and argon fill }\end{array}$ \\
\hline $\begin{array}{l}\text { Atlanta Case Study (2- } \\
\text { year study) }\end{array}$ & $\begin{array}{c}\text { DOE, } \\
\text { Quanta, } \\
\text { Larson, } \\
\text { (b) } \\
\text { NAHB, ACG } \\
\text { Flat Glass, and } \\
\text { NSG- } \\
\text { Pilkington }\end{array}$ & $\begin{array}{l}10 \text { occupied homes; } \\
\text { single-pane wood } \\
\text { framed windows }\end{array}$ & $\begin{array}{l}\text { High variability, but approximately: } \\
\text { - } \sim 15 \% \text { heating energy reduction } \\
\text { - } \sim 2 \text { to } 30 \% \text { cooling reduction (highly variable) } \\
\text { - } 17 \% \text { reduction in overall home air infiltration }\end{array}$ \\
\hline $\begin{array}{l}\text { Philadelphia } \\
\text { Multifamily Case Study }\end{array}$ & $\begin{array}{l}\text { DOE, Quanta, } \\
\text { Larson, } \\
\text { NAHB, AGC } \\
\text { Flat Glass, } \\
\text { NSG- } \\
\text { Pilkington }\end{array}$ & $\begin{array}{l}2 \text { large multifamily } \\
\text { buildings; single- } \\
\text { pane, metal framed } \\
\text { windows }\end{array}$ & $\begin{array}{l}\text { Replacing old clear glass storm windows with new } \\
\text { low-e storm windows provided: } \\
\text { - } 18-22 \% \text { reduction in heating energy use } \\
\text { - } 9 \% \text { reduction in cooling energy use } \\
\text { - } 10 \% \text { reduction in overall apartment air leakage }\end{array}$ \\
\hline $\begin{array}{l}\text { Field Air-Leakage } \\
\text { Testing (Bronx, NY, } \\
\text { 2013) }\end{array}$ & $\begin{array}{l}\text { Steven Winter } \\
\text { Associates, } \\
\text { Quanta }\end{array}$ & $\begin{array}{l}\text { Multifamily } \\
\text { dwellings in Bronx }\end{array}$ & $\begin{array}{l}\text { Interior low-e panels reduced the effective leakage } \\
\text { area by: } \\
\text { - } 77 \% \text { for windows without air-conditioning units } \\
\text { - } 95 \% \text { for windows with air-conditioning units }\end{array}$ \\
\hline $\begin{array}{l}\text { Pennsylvania } \\
\text { Weatherization } \\
\text { technical support (2010) }\end{array}$ & $\begin{array}{l}\text { DOE, Birch } \\
\text { Point } \\
\text { Consulting }\end{array}$ & $\begin{array}{l}37 \text { model homes with } \\
\text { range of window } \\
\text { types }\end{array}$ & $\begin{array}{l}\text { Modeled results for } 7 \text { climate zones: } \\
\text { • } 12 \% \text { to } 33 \% \text { overall HVAC savings }\end{array}$ \\
\hline
\end{tabular}

(a) Quanta Technologies, Inc., Malvern, Pennsylvania.

(b) Larson Manufacturing Company, Brookings, South Dakota.

Sources and documentation for case study results include Drumheller et al. (2007), Quanta Technologies (2013), and Zalis et. al. (2010).

AGC = Asahi Glass Company; HUD = U.S. Department of Housing and Urban Development; LBNL = Lawrence Berkeley National Laboratory; NAHB = National Association of Home Builders. 
Although field data and case studies provide valuable insights related to the savings potential of low-e storm windows in specific applications or climate zones, the variability that occurs due to home types and occupancy behavior can make it difficult to isolate the savings from the fenestration attachment and project these savings in alternative circumstances. Controlled side-by-side experiments, such as those conducted in the PNNL Lab Homes, provide a platform for more detailed and comprehensive data collection on the whole-house energy and comfort performance of low-e storm windows. Building simulation models can also be useful tools for assessing appropriate applications and savings in multiple scenarios and climate zones, but simulations rely on accurate field data to appropriately characterize performance and calibrate the tools. The PNNL Lab Homes will provide controlled experimental wholehouse data, which can be used to appropriately tailor and calibrate building simulation models to account for relevant interactions, occupancy, climate zones, and baseline characterizations.

This side-by-side evaluation in the PNNL Lab Homes represents the first controlled whole-house experiments performed on low-e storm windows. The data collected as a result of the PNNL Lab Homes experiments can complement previous modeling and field studies to help describe the performance of exterior low-e storm windows as a retrofit option for typical residential homes. The detailed results describe the performance of the low-e storm windows more precisely than field studies, because the experiments are not confounded by weather or occupancy impacts, and thus can also be used to calibrate whole-house energy models. 


\subsection{Experimental Design}

The evaluation of low-e storm windows took place in the PNNL Lab Homes between March 2013 and March 2014. This section describes the experimental timeline, the Lab Homes, the low-e storm windows used in the experiment, and the data collection and analysis approach.

\subsection{Lab Homes}

The experiments were conducted in PNNL's side-by-side Lab Homes, which form a platform for precisely evaluating energy-saving and grid-responsive technologies in a controlled environment. The PNNL Lab Homes (http://labhomes.pnnl.gov/) comprise two factory-built homes recently installed on PNNL's campus in Richland, Washington. Each Lab Home has seven windows and two sliding glass doors that have a total of $196 \mathrm{ft}^{2}$ of window area. For the primary experiments examined in this study, the "Experimental Home” (Lab Home B) is retrofit with exterior low-e storm windows while a matching baseline home (Lab Home A) is not equipped with any additional window attachments. The floor plan of the Lab Homes as constructed is shown in Figure 3.1. Figure 3.1 shows the south facing side of the building at the top, thus the right, bottom, and left sides are west, north, and east facing, respectively.

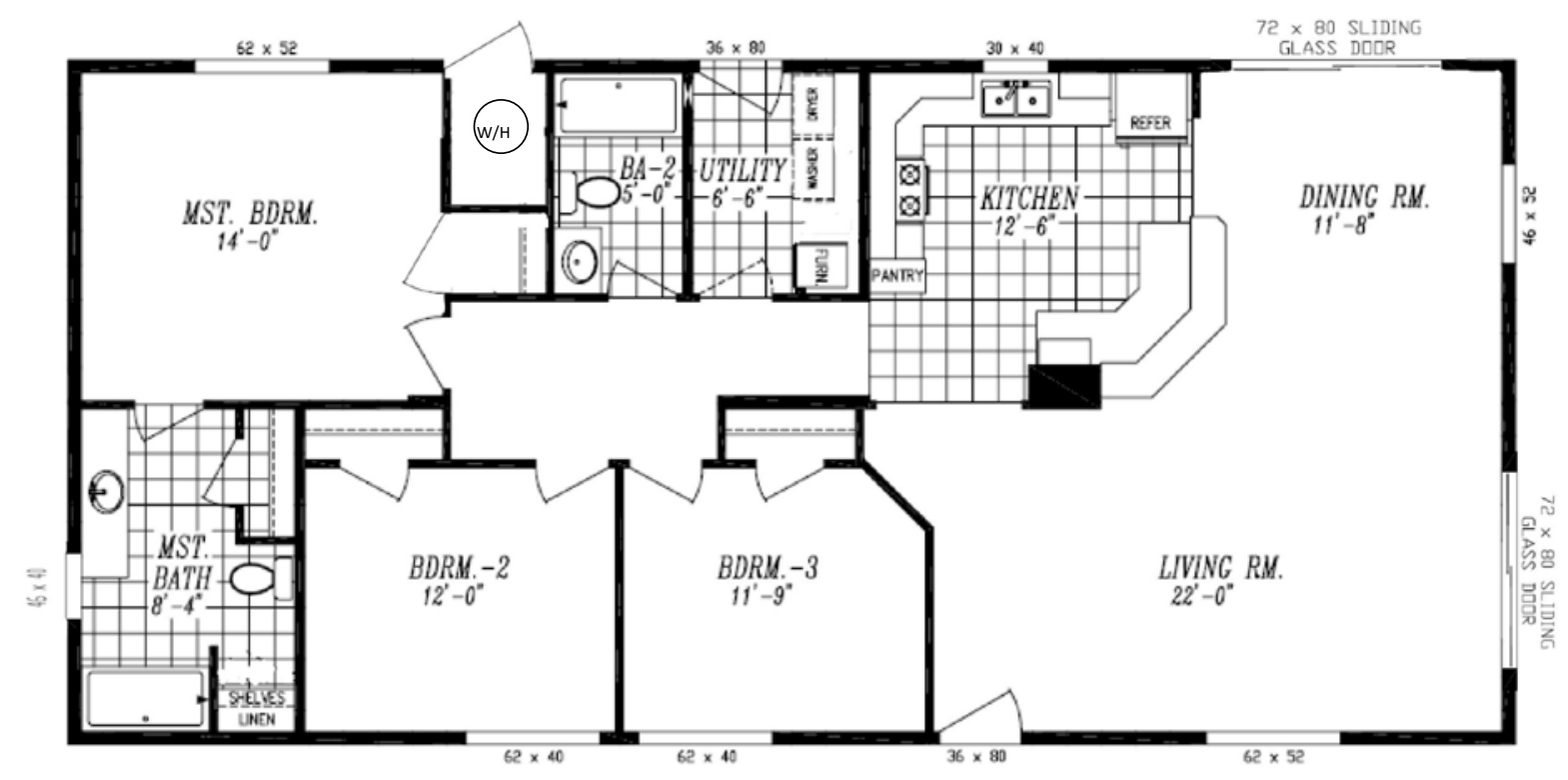

Figure 3.1. Floor Plan of the Lab Homes as Constructed

\subsection{Windows Retrofit}

The primary windows and patio doors currently installed in both of the Lab Homes are double-pane, clear-glass aluminum-frame sliders. For the experiment, low-e storm windows were installed over Lab Home B's windows and sliding glass doors. Larson Silver Series Exterior low-e two-track storm windows and doors with half screens (Model number L603E, in white) were installed using the overlap 
method in accordance with manufacturer's instructions ${ }^{1}$ to replicate typical homeowner installation. The storm windows are designed to allow permanent installation. ${ }^{2}$. The number and dimensions of the windows are as follows:

- 2 ea 62" X 52" - Two-track Sliders

- 2 ea 62" X 40" - Two-track Sliders

- 1 ea 30" X 40" - Two-track Sliders

- 1 ea 46" X 42" - Two-track Sliders

- 1 ea 24" X 40" - Single Hung

- 2 ea 72" X 80" -Sliding glass doors

Due to the construction of the Lab Homes, the primary window frames extend about $1 / 2-3 / 4$ in. beyond the plane of the exterior siding and window trim on both Lab Homes. Thus, in order to achieve a thermal break between the existing aluminum window frame and the low-e storm window, wooden 2 x 4in. and 1 x 4-in. boards were installed around all the windows on the outside of Lab Home B, on top of existing trim, as a mounting surface for the exterior low-e storm windows, as shown in Figure 3.2. This allowed the storm windows to be installed with no direct contact with the metal frame of the primary window, which in addition to the benefits of the additional low-e glazing layer, helps reduce the thermal bridging of the metal frame in the primary window. This is also typical of installation in real homes, where the storm window is attached to surrounding brick mold or trim, not to the primary window frame itself. The exterior storm windows were applied over the outside of the window with screws and caulk. Note, the bottom edge of the low-e storm window contains weep holes to allow the drainage of any moisture that intrudes into the cavity between the primary window and the storm window and, thus, is not to be sealed. The installation process of the low-e storm windows is described in detail in Appendix A. Installing exterior low-e storm windows is a relatively simple process that is accomplishable by most homeowners; it does not require a professional to complete.

\footnotetext{
${ }^{1}$ http://www.larsondoors.com/images/uploads/window_install.pdf

2 In this experimental design, the low-e storm windows were removed at the end of each experimental period to accommodate other experiments in the Lab Homes.
} 


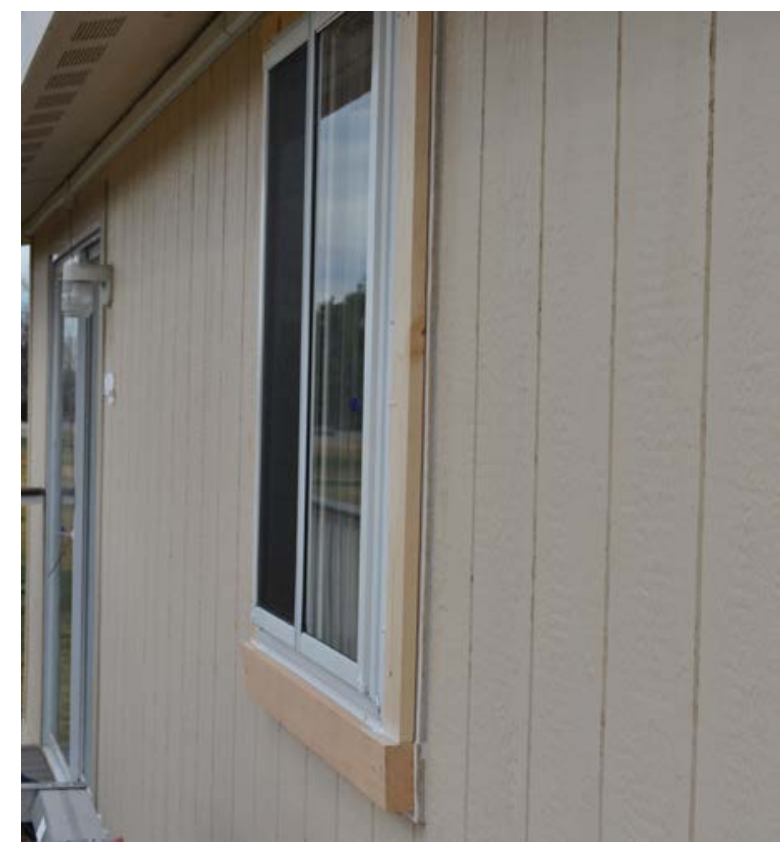

Figure 3.2. Mounting Surface for Exterior Storm Windows in Lab Homes B

\subsubsection{Exterior Low-E Storm Window Performance Ratings}

The U-factor and solar heat gain coefficient (SHGC) for the primary windows are listed in Table 3.1. Based on simulations performed by Architectural Testing, Inc., ${ }^{1}$ the U-factor and SHGC of the combined system, including a primary window covered by either an exterior or interior low-e storm window, is estimated to be approximately $0.33 \mathrm{Btu} / \mathrm{hr}^{-\mathrm{ft}^{2}}{ }^{\circ} \mathrm{F}$ and 0.53 , respectively (Culp et al. 2013). This is roughly a $52 \%$ reduction in U-factor and $24 \%$ reduction in SHGC. The simulations were performed for both exterior and interior low-e storm windows installed in combination with different types of primary windows. The addition of the exterior storm windows, together with the primary windows, essentially creates a triple-pane low-e glazing system. For comparison, a triple-pane R-5 window has a U-factor of 0.2, a SHGC of 0.19, and a VT of 0.36 (Widder 2012) and also includes inert gas such as argon and a highly insulated frame.

Table 3.1. Primary Window Characteristics

\begin{tabular}{lcccc}
\hline & \multicolumn{2}{c}{ Primary Windows in Lab Homes A and B } & \multicolumn{2}{c}{ Lab Home B with Low-E Storm Windows } \\
\cline { 2 - 5 } \multicolumn{1}{c}{ Value } & Windows & Patio Doors & Windows & Patio Doors \\
\hline U-factor (Btu/hr-ft ${ }^{2}$-F) & 0.68 & 0.66 & 0.33 & 0.32 \\
SHGC & 0.7 & 0.66 & 0.53 & 0.5 \\
VT & 0.73 & 0.71 & 0.61 & 0.59 \\
\hline VT = visible transmittance. & \multicolumn{5}{c}{} \\
\hline
\end{tabular}

Although the NFRC provides U-factor ratings for primary windows, there is currently no standard performance or energy-efficiency rating system that exists for storm windows or other window

\footnotetext{
${ }^{1}$ Architectural Testing, Inc performed a detailed thermal simulation using WINDOW6/THERM6 in accordance with National Fenestration Rating Council (NFRC) procedures and accounted for how low-e storm windows are realistically attached over existing primary windows (Culp et al. 2013).
} 
attachments. To address the lack of a nationally-recognized rating system for storm windows or other fenestration attachments, the U.S. DOE has recently issued a funding announcement ${ }^{1}$ to develop a thirdparty program that creates a consistent set of energy performance-based rating and certification standards and program procedures for energy-efficient fenestration attachments. The program would oversee the implementation of rating, certification, labeling, and performance verification procedures; and develop and maintain a publicly available, searchable electronic database of fenestration attachment product performance.

\subsection{Experimental Timeline}

A timeline of the operating parameters and experimental scenarios exercised during the data collection periods is presented in Table 3.2. The thermostat set point in the cooling season was set to $70^{\circ} \mathrm{F}$ and the heating season set point was $75^{\circ} \mathrm{F}$ with no set-backs. The set points were chosen to generate a large temperature differential between indoors and outdoors to maximize the observed HVAC impacts while keeping the set points still in a range that is representative of real home performance. The low-e storm windows were first installed in March 2013 and an initial 2013 heating season experiment was run to preliminarily evaluate the energy savings, but only for 2 weeks because of scheduling conflicts in the Lab Homes. Additional heating season data were collected from January to March 2014. Cooling season data were collected in August 2013 and September 2013.

In both the heating season and the cooling season, the impact of interior blinds on low-e storm window performance was evaluated. The interior blinds in the Lab Homes are typical white venetian blinds over the windows and vertically hung slat blinds for the sliding glass doors. To understand the impact of blinds on the observed performance of low-e storm windows, both the heating and the cooling season included a period where the blinds were closed in at least one home. In the cooling season the blinds in Lab Home B only were closed, which would tend to incrementally increase savings in Lab Home B as compared to Lab Home A, and in the heating season the blinds in both homes were closed, which would be expected to slightly decrease the energy use and savings attributable to the low-e storm windows.

\footnotetext{
${ }^{1}$ http://www1.eere.energy.gov/financing/solicitations_detail.html?sol_id=652
} 
Table 3.2. Experimental Timeline

\begin{tabular}{lll}
\hline Activity & Start Date & End Date \\
\hline INITIAL WINTER EXPERIMENT & & \\
\hline Low-e Storm window installation and air-leakage testing & $2 / 28 / 13$ & $3 / 6 / 13$ \\
Low-e Storm window installation and air-leakage testing & $3 / 14 / 13$ & $3 / 14 / 13$ \\
Heating season data collection & $3 / 14 / 13$ & $3 / 27 / 13$ \\
End initial 2013 heating season data collection & $3 / 28 / 13$ & $3 / 28 / 13$ \\
\hline SUMMER EXPERIMENT & & \\
Low-e Storm window installation and air-leakage testing & $8 / 20 / 2013$ & $8 / 20 / 2013$ \\
Baseline testing & $8 / 16 / 2013$ & $8 / 19 / 2013$ \\
Cooling season data collection & $8 / 20 / 2013$ & $8 / 26 / 2013$ \\
Blinds closed in Lab Home B & $8 / 27 / 2013$ & $9 / 2 / 2013$ \\
Data lost because of HVAC shutdown & $9 / 2 / 2013$ & $9 / 6 / 2013$ \\
Bottom edge of storm windows sealed & $9 / 7 / 2013$ & $9 / 11 / 2013$ \\
End cooling season data collection & $9 / 12 / 2013$ & $9 / 12 / 2013$ \\
WINTER EXPERIMENT & & \\
Low-e Storm window installation & $1 / 24 / 2014$ & $1 / 24 / 2014$ \\
Baseline testing & $1 / 22 / 2014$ & $1 / 24 / 2014$ \\
Heating season data collection & $1 / 25 / 2014$ & $2 / 11 / 2014$ \\
Power outage in Lab Home A & $2 / 12 / 2014$ & $2 / 14 / 2014$ \\
Blinds closed in both Lab Homes & $2 / 15 / 2014$ & $3 / 8 / 2014$ \\
Installed Low-e Interior storm windows in Lab Home A & $3 / 9 / 2014$ & $3 / 25 / 2014$ \\
End heating season data collection & $3 / 26 / 2014$ & $3 / 26 / 2014$ \\
\hline HVAC = heating, ventilation, and air-conditioning. & & \\
\hline
\end{tabular}

\subsection{Metering Approach}

The approach to the metering includes metering and system-control activities taking place at both the electrical panel and at the end-use. Monitoring is broken into electrical (Table 3.3) and temperature/other (Table 3.4). Each table highlights the performance metric (the equipment/system being monitored), the monitoring method and/or point, the monitored variables, and the data application. 
Table 3.3. Electrical Points Monitored

\begin{tabular}{|c|c|c|c|}
\hline $\begin{array}{l}\text { Performance } \\
\text { Metric }\end{array}$ & $\begin{array}{c}\text { Monitoring } \\
\text { Method/Points }\end{array}$ & $\begin{array}{l}\text { Monitored } \\
\text { Variables }\end{array}$ & Data Application \\
\hline $\begin{array}{l}\text { Whole Building } \\
\text { Energy Use }\end{array}$ & $\begin{array}{l}\text { Electrical panel } \\
\text { mains }\end{array}$ & $\mathrm{kW}$, amps, volts & $\begin{array}{l}\text { Comparison between homes of } \\
\text { - } \text { power profiles } \\
\text { - } \text { time-series energy use } \\
\text { differences and savings }\end{array}$ \\
\hline $\begin{array}{l}\text { HVAC Energy } \\
\text { Use (heat pump) }\end{array}$ & $\begin{array}{l}\text { Panel metering } \\
\text { compressor } \\
\text { Panel metering air } \\
\text { handling unit } \\
\text { End-use metering } \\
\text { condensing unit (CU) } \\
\text { fan/controls }\end{array}$ & $\begin{array}{l}\mathrm{kW} \text {, amps, volts } \\
\mathrm{kW} \text {, amps, volts } \\
\mathrm{kW} \text {, amps, volts }\end{array}$ & $\begin{array}{l}\text { Comparison and difference calculations between } \\
\text { systems of } \\
\text { - power profiles } \\
\text { - time-series energy use } \\
\text { - differences and savings }\end{array}$ \\
\hline $\begin{array}{l}\text { HVAC Energy } \\
\text { Use (ventilation) }\end{array}$ & $\begin{array}{l}\text { Panel metering of } 3 \\
\text { ventilation breakers } \\
\text { ( } 2 \text { bathroom and } \\
\text { whole-house fans) }\end{array}$ & $\mathrm{kW}$, amps, volts & $\begin{array}{l}\text { Comparison and difference calculations between } \\
\text { systems of } \\
\text { - } \quad \text { power profiles } \\
\text { - } \text { time-series energy use } \\
\text { - differences and savings }\end{array}$ \\
\hline $\begin{array}{l}\text { Appliances and } \\
\text { Lighting }\end{array}$ & $\begin{array}{l}\text { Panel metering of all } \\
\text { appliance and } \\
\text { lighting breakers }\end{array}$ & $\mathrm{kW}$, amps, volts & Comparison and difference calculations. \\
\hline
\end{tabular}

Table 3.4. Temperature and Environmental Points Monitored

\begin{tabular}{|c|c|c|c|}
\hline $\begin{array}{c}\text { Performance } \\
\text { Metric }\end{array}$ & Monitoring Method/Points & Monitored Variables & Data Application \\
\hline \multirow[t]{2}{*}{$\begin{array}{l}\text { Space } \\
\text { Temperatures }\end{array}$} & $\begin{array}{l}13 \text { Ceiling-hung } \\
\text { thermocouples/1-2 sensors } \\
\text { per room/area, and } 1 \text { HVAC } \\
\text { duct supply temperature per } \\
\text { home }\end{array}$ & Temp. ${ }^{\circ} \mathrm{F}$ & $\begin{array}{l}\text { Comparison and difference calculations } \\
\text { between homes of } \\
\text { - temperature profiles } \\
\text { - time-series temperature changes }\end{array}$ \\
\hline & $\begin{array}{l}2 \text { mean radiant sensors per } \\
\text { home (main living area, } \\
\text { master bedroom) }\end{array}$ & Temp. ${ }^{\circ} \mathrm{F}$ & \\
\hline $\begin{array}{l}\text { Glass Surface } \\
\text { Temperatures }\end{array}$ & $\begin{array}{l}22 \text { thermocouples ( } 2 \text { sensors } \\
\text { per window interior/exterior } \\
\text { center of glass); west } \\
\text { window with } 6 \text { sensors. } 2 \\
\text { thermocouples per home to } \\
\text { measure temperature } \\
\text { between the primary and } \\
\text { storm windows. }\end{array}$ & Temp. ${ }^{\circ} \mathrm{F}$ & $\begin{array}{l}\text { Comparison and difference calculations } \\
\text { between homes of } \\
\text { • temperature profiles } \\
\text { - time-series temperature changes }\end{array}$ \\
\hline $\begin{array}{l}\text { Through-Glass } \\
\text { Solar } \\
\text { Radiation }\end{array}$ & $\begin{array}{l}1 \text { pyranometer sensor per } \\
\text { home trained on west-facing } \\
\text { window }\end{array}$ & $\mathrm{W} / \mathrm{m}^{2}$ & $\begin{array}{l}\text { Comparison and difference calculations } \\
\text { between homes of } \\
\text { - profiles by window and location }\end{array}$ \\
\hline
\end{tabular}


All metering was completed using Campbell ${ }^{\circledR}$ Scientific data loggers and matching sensors. Two Campbell data loggers were installed in each home, one allocated to electrical measurements and one to temperature and other data collection. Data from all sensors were collected via cellular modems that were individually connected to each of the loggers.

All data were captured at 1-minute intervals by the Campbell ${ }^{\circledR}$ Scientific data loggers. These 1-minute data were averaged over hourly and daily time intervals to afford different analysis activities.

Occupancy in the homes was simulated via a programmable commercial lighting breaker panel (one per home) using motorized breakers. These breakers were programmed to activate connected loads on schedules to simulate human occupancy by introducing heat to the space. 


\subsection{Results and Discussion}

The air-leakage, energy, and thermal comfort performance of exterior low-e storm window were evaluated during the heating season and cooling season in 2013 and 2014 in the PNNL Lab Homes. The subsequent sections provide a summary of the baseline performance of the two homes, as well as a comparison of the infiltration, energy, and thermal comfort performance of Lab Home B equipped with exterior low-e storm windows and Lab Home A equipped with double-pane clear-glass windows and no attachments. A preliminary evaluation of the energy and thermal performance of interior low-e storm windows was also completed in March 2014 and comparative energy savings data is presented in section 6.0. Note that all experimental results are presented, in general, as daily averages with $95 \%$ confidence intervals calculated for each measured quantity, assuming a normal distribution of the data and applying a student's t-statistic. The 95\% confidence interval is then used to establish the significance of the differences observed as a result of the low-e storm window retrofit by applying a traditional significance test.

\subsection{Baseline Performance}

Prior to installing the exterior storm windows in both the heating and cooling season, baseline performance data were collected over 3 days in each season to ensure that the homes HVAC and simulated occupancy systems were operating identically. Over the 6 days of baseline data collection from the heating and cooling season, the energy use in Lab Home B and Lab Home A was observed to be statistically the same, within 3\%. Specifically, Lab Home B used $0.94 \pm 2.82 \%$ more energy per day than Lab Home A over the baseline period. The baseline period allowed verification that the energy use of the monitored metrics (HVAC, occupancy, lighting, equipment, and the water heater) were equivalent in both homes prior to installation of the low-e storm windows in the Experimental Home (Lab Home B). Figure 4.1 depicts the cumulative energy use of Lab Home A versus Lab Home B during the base lining period on a representative day. The $45^{\circ}$ red line represents equal energy use in both homes and the blue line of the measured data follows it almost exactly. Similar performance was observed on the other baseline days. 


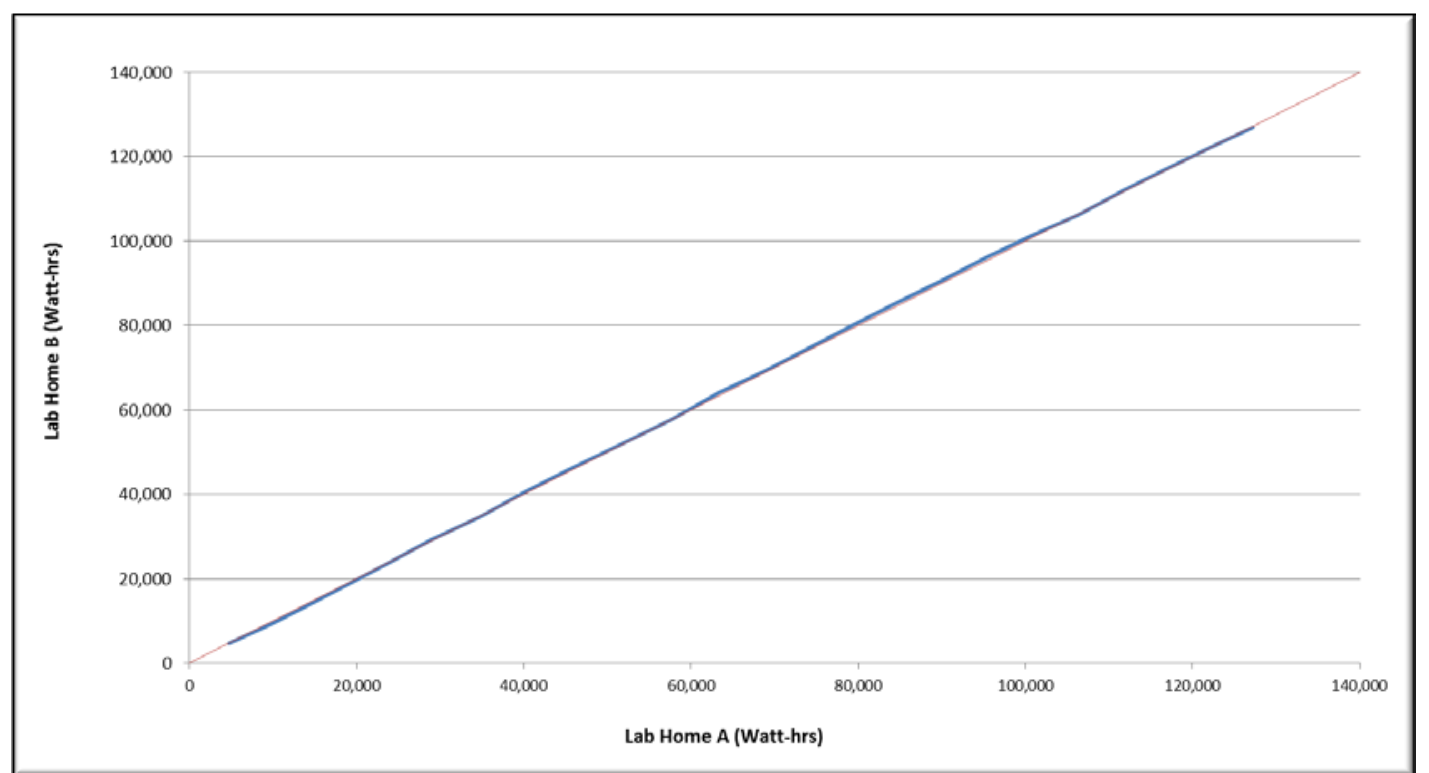

Figure 4.1. Cumulative Energy Use of Lab Home B (Experimental Home) Versus Lab Home A (Baseline Home) during Baselining of the Homes

\subsection{Building Shell Air Leakage}

Building shell air leakage in both Lab Homes was measured prior to the beginning of the experiment to obtain a baseline reading on the homes and ensure equivalent air-leakage performance between the two homes. Prior to the low-e storm windows installation, the blower door test ${ }^{1}$ results showed the air leakage of the two homes to be statistically the same, with 95\% confidence, as shown in Table 4.1. Lab Home A had an air-leakage rate of $789.7 \pm 25.7 \mathrm{cfm}$ at 50 Pa depressurization (cfm50) with respect to the outside and Lab Home B had an air leakage of $820.1 \pm 26.5 \mathrm{cfm} 50$. Accounting for experimental error in the blower door measurement and the blower door instrument accuracy, the two homes demonstrated equivalent rates air leakage with 95\% confidence prior to installing low-e storm windows on the Experimental Home (Lab Home B). The calculated air changes per hour at 50 Pa depressurization with respect to the outside (ACH50) and air changes per hour at normal pressurization $\left(\mathrm{ACH}_{\mathrm{n}}\right)$ are also presented in Table 4.1.

After installation of the exterior storm windows on Lab Home B, the home was retested for air leakage in a variety of scenarios and the results are tabulated in Table 4.2. These tests evaluate the relative leakiness of the primary window as compared to the storm window, to determine which window forms the primary air barrier for the home and suggest the relative contribution of each to any reduction in whole-house air leakage. Blower door tests were performed in the following configurations:

- primary windows open and storm windows closed (storm window only),

- primary windows closed and storm windows open (primary window only), and

- primary windows and storm windows closed (both primary and storm window).

\footnotetext{
${ }^{1}$ Blower door testing equipment measures flow with an accuracy of $\pm 3 \%$. http://www.energyconservatory.com/products/automated-blower-door-systems-and-accessories
} 
Table 4.1. Blower Door Test Results Prior to Storm Windows Installation

\begin{tabular}{lcccc}
\hline & \multicolumn{2}{c}{ Baseline Lab Home A } & \multicolumn{2}{c}{ Experimental Lab Home B } \\
\cline { 2 - 5 } Parameter & Average Value & $\begin{array}{c}\text { 95\% Confidence } \\
\text { Interval }\end{array}$ & $\begin{array}{c}\text { A5\% Confidence } \\
\text { Interval }\end{array}$ \\
\hline cfm50 (a) & 789.7 & 25.7 & 820.1 & 26.5 \\
$\mathrm{ACH50}$ & 3.80 & 0.12 & 3.95 & 0.13 \\
$\mathrm{ACH}_{\mathrm{n}}{ }^{(\mathrm{b})}$ & 0.18 & 0.01 & 0.18 & 0.01 \\
\hline
\end{tabular}

(a) Cubic feet per minute at 50 Pascals depressurization

(b) $\mathrm{n}=21.5$, based on single-story home in climate zone 3 , with minimal shielding

It may be hypothesized that the air-leakage performance of exterior low-e storm windows may be able to be further improved by more careful sealing of the bottom edge of the window frame. However, this is not recommended by the manufacturer due to the potential risk of sealing the weep holes and subsequent durability concerns from moisture intrusion. Manufacturers also claim that the incremental improvement in air-leakage performance is not significant due to the location of the weep holes. Specifically, since the weep holes are only located at the bottom of the window, the generation of stack and airflow within the gap is limited because the air has to go in and out the same hole. Pressure dynamics make significant air movement simultaneously into and out of the window cavity very unlikely. To evaluate this claim and the potential improvement in air-leakage performance resulting from sealing the bottom edge of the low-e storm window, the air leakage of the storm window only (primary window open and storm window closed) and the primary and storm window together (both closed) was also measured with a blower door after sealing the bottom edge of the storm window.

Table 4.2. Blower Door Test Results after Exterior Storm Window Installation

\begin{tabular}{|c|c|c|c|c|}
\hline \multirow[b]{2}{*}{$\begin{array}{l}\text { Primary } \\
\text { Window }\end{array}$} & \multirow[b]{2}{*}{$\begin{array}{c}\text { Storm } \\
\text { Window }\end{array}$} & \multirow{2}{*}{$\begin{array}{c}\text { Bottom } \\
\text { Edge of } \\
\text { Storm } \\
\text { Window }\end{array}$} & \multicolumn{2}{|c|}{$\begin{array}{c}\text { Lab Home B } \\
\text { Experimental Home }\end{array}$} \\
\hline & & & $\begin{array}{l}\text { Average Value } \\
\text { (cfm50) }\end{array}$ & $\begin{array}{l}\text { 95\% Confidence } \\
\text { Interval }\end{array}$ \\
\hline Closed & Open & Unsealed & 842.0 & 31.4 \\
\hline Open & Closed & Unsealed & $1,445.9$ & 58.9 \\
\hline Closed & Closed & Unsealed & 803.1 & 29.3 \\
\hline Open & Closed & Sealed & $1,316.3$ & 58.4 \\
\hline Closed & Closed & Sealed & 841.8 & 41.9 \\
\hline
\end{tabular}

The installation of the storm windows on Lab Home B reduced the air leakage in the home from $820.1 \pm 26.5 \mathrm{cfm} 50$ to $803.1 \pm 29.3 \mathrm{cfm} 50$, which is a $17.0 \pm 25.2 \mathrm{cfm} 50$, or $2.1 \pm 3.1 \%$, reduction. This is the reduction in air leakage for the entire Lab Home just from the addition of storm windows; no other air sealing measures were applied to the home. The decrease in air leakage is not statistically significant, with 95\% confidence because the error in the measurements is greater than the average difference between the measurements. When the blower door test was run with the storm window as the primary air barrier with the main window open, the air leakage was measured at $1445.9 \pm 58.9 \mathrm{cfm} 50$, which is much higher than the measured leakage of $842.0 \pm 31.4 \mathrm{cfm} 50$ with only the primary windows acting as an air barrier and the storm windows open. With both the primary and storm windows closed, the measured air leakage was $803 \pm 29.3 \mathrm{cfm} 50$, which is slightly lower than the value measured with only the primary 
window as the air barrier, but not significantly so. This testing suggests that for Lab Home B the primary window remains the primary air barrier and, the closed storm window provides no statistically significant reduction in air leakage. However, it should be noted that the Lab Homes are relatively airtight with less than 4 ACH50, whereas air leakage in older homes is commonly much higher. For homes that have leakier windows, installing exterior storm windows could have a more significant impact on the air leakage than seen here.

Previous field studies have demonstrated significant reductions in air leakage from the application of exterior storm windows. In a previous case study of five Chicago weatherization homes, an average 7\% reduction in overall home air leakage was observed from the addition of exterior storm windows (Drumheller et al. 2007). In addition, an average 10\% reduction in overall apartment air leakage was observed for a field study of low-e storm windows on two large apartment buildings in Philadelphia, and an average $17 \%$ average reduction in overall home air leakage was observed for storm windows used in 10 older weatherization homes near Atlanta (Culp et al. 2013). The reduction in air leakage observed in these case studies was greater than reductions observed in Lab Home B, most likely due to the higher initial leakiness of the primary existing windows in these older buildings.

A blower door test was also performed with the bottom edge of the storm window sealed to determine if the uncaulked bottom sill was a significant source of air leakage. The bottom edge of the storm windows and the weep holes were sealed with tape to simulate the caulking of the bottom edge of the storm window ${ }^{1}$. With the bottom edge of the storm window sealed, Lab Home B had an air leakage of $841.8 \pm 25.3 \mathrm{cfm} 50$, which is statistically the same as that measured with the bottom edge unsealed. This suggests that leaving the bottom edge and weep holes unsealed as recommended in the manufacturer instructions does not have any significant detrimental effect on overall air leakage. Because there is no statistical difference, the data derived from the experimental periods when the bottom edges of the storm windows were sealed can be combined with the data derived when the bottom edge was unsealed. This has been done in the subsequent analysis.

\subsection{Low-E Storm Window Energy Performance}

After retrofitting Lab Home B with exterior low-e storm windows, experimental data were collected from August 16 to September 11, 2013, to characterize the energy and thermal performance of the windows during the cooling season and January 22 to March 25, 2014, to characterize performance during the heating season. Heating season performance was also tested from March 14 to March 28, 2013, and those data are included in the heating season performance described in Section 4.3.2.

To compare and assess the performance of the exterior storm windows relative to the baseline windows, energy use and interior and glass surface temperatures were compared on an average daily basis. This comparison shows significant whole-house energy savings in the Lab Home with the low-e storm windows installed (Lab Home B). The overall whole-house savings are $10.5 \pm 1.2 \%$ in the heating season and $8.0 \pm 0.5 \%$ in the cooling season.

\footnotetext{
${ }^{1}$ To conduct this short term experiment, the bottom sill of the storm windows were sealed with painters tape. For a more permanent installation, caulk or other more durable material should be used.
} 


\subsubsection{Summer Cooling Season Results}

Cooling during the summer was provided by a 2.5-ton seasonal energy-efficiency ratio (SEER) 13 heat pump. During the cooling season the exterior storm windows resulted in a daily energy savings of $3,623 \pm 349$ Wh (Table 4.3), which is an $8.0 \pm 0.5 \%$ reduction in whole-house cooling energy use. These savings are primarily due to the decrease in U-factor and the reduced SHGC from the low-e storm windows.

To determine the incremental impact of blinds on the low-e storm window savings, the blinds in Lab Home B were closed for a portion of the cooling season experiment. Closing the blinds in Lab Home B increased the energy savings to an average of 5,680 $\pm 647 \mathrm{Wh} / \mathrm{d}$. This is expected because the blinds further reduce the amount of solar heat gain inside the home and decrease the U-factor of the window by about $0.1 \mathrm{Btu} / \mathrm{hr}_{\mathrm{ft}}{ }^{2}$-F (Curcija et al. 2013). If the blinds in both Lab Homes had been closed, one would expect both the total energy use and energy savings to decrease compared to if the blinds were left open at all times. By closing the blinds in both homes the effects of solar heat gain would be mostly eliminated, thus lowering total energy use, and Lab Home B's advantage of having windows with a lower SHGC due to the low-e storm windows would be reduced or eliminated, thus reducing the energy savings, although the benefit of lower U-factor would remain.

Table 4.3. Average Daily Energy Savings and 95\% Confidence Interval from Low-E Storm Windows Without and With Blinds

\begin{tabular}{lcccc}
\hline \multicolumn{1}{c}{ Operating Scenario } & $\begin{array}{c}\text { Average } \\
\text { Savings } \\
(\text { Wh) }\end{array}$ & $\begin{array}{c}\text { 95\% Confidence } \\
\text { Interval } \\
(\text { Wh })\end{array}$ & $\begin{array}{c}\text { Average } \\
\text { Savings } \\
(\%)\end{array}$ & $\begin{array}{c}95 \% \text { Confidence } \\
\text { Interval } \\
(\%)\end{array}$ \\
\hline With Storm Windows in Lab Home B & 3,623 & 349 & 8.0 & 0.5 \\
With Blinds Closed 24 hr/d in Lab Home B & 5,680 & 647 & 12.0 & 1.5 \\
\hline
\end{tabular}

\subsubsection{Winter Heating Season Results}

Heating during the winter was provided solely by a forced-air electric resistance furnace. Although a variety of heating systems and fuel types are used in homes, using electric resistance heating allows precise direct measurement of thermal energy impact of the low-e storm windows in the Lab Home experiments, because the electric resistance elements are $100 \%$ efficient. These results can then be easily extrapolated to other heating system types based on the relative efficiency of that system.

The energy performance of the low-e storm windows was initially evaluated from March $14^{\text {th }}$ to March $28^{\text {th }}$ during the 2013 (referred to as the initial 2013 heating season evaluation). During this initial 2013 heating season evaluation, average daily whole-house energy savings of 5,404 $\pm 1,678 \mathrm{Wh}$, or 10.3 $\pm 2.3 \%$, were observed with $95 \%$ confidence. The average outdoor air temperature during this experimental period was $46.9 \pm 3.8^{\circ} \mathrm{F}$. The percent savings seen in the initial 2013 heating season are statistically the same as the savings seen in the main heating season experiment, as shown in Table 4.4.

During the full heating season evaluation from January 25 to February 11, 2014, the exterior low-e storm windows resulted in a daily energy savings of $14,251 \pm 2,720 \mathrm{Wh}$, as shown in Table 4.4 , which is a $10.5 \pm 1.2 \%$ reduction in whole-house energy use. The magnitude of daily whole-house energy use and, thus, energy savings are primarily driven by the very low outdoor air temperatures. The average outdoor 
air temperature during the heating season evaluation was $28.3 \pm 3.9^{\circ} \mathrm{F}$, which led to high energy consumption and commensurately high energy savings, in Wh/d, during this part of the experiment. This high energy consumption is highlighted when comparing the average daily savings from this period to the initial 2013 heating season evaluation. The percent savings from the initial and full 2014 heating season evaluations (March 14 to 28, 2013, and January 25 to February 11, 2014, respectively) were observed to be statistically the same despite the fact that the average outdoor temperature was about $20^{\circ} \mathrm{F}$ lower in the 2014 heating season experimental period, which resulted in approximately an additional 8,800 Wh/d of savings.

The impact of interior blinds on whole-house energy use was also evaluated in the heating season from February $15^{\text {th }}$ to March $8^{\text {th }}$, 2014. In this experiment the blinds in both homes were closed to determine how blinds would affect or mitigate the observed savings due to the low-e storm windows. When the blinds were closed in both homes, the average daily absolute energy savings decreased from $14,251 \pm 2,720 \mathrm{Wh}$ to $11,819 \pm 1,707 \mathrm{Wh}$, in part caused by the decrease in beneficial solar heat gain which offsets heating demand, but also caused by an increase in the average outdoor air temperature during this period. The average outdoor air temperature for when the blinds were closed was $42.2 \pm 3.5^{\circ} \mathrm{F}$. Due to the impact of varying outdoor air temperatures on the observed Wh/d savings, the percent energy savings is a more appropriate metric for comparing energy savings between two periods. The percent energy savings observed with the blinds closed was $11.1 \pm 0.9 \%$, which is not statistically different than the energy savings measured with the blinds fully open (10.5 $\pm 1.2 \%)$, as shown in Table 4.4. One would expect the percent savings to increase when the blinds are closed because the beneficial solar heat gains to the conditioned space would be blocked and Lab Home A with the clear-glass windows would lose more free heating from the sun compared to Lab Home B because the SHGC of the clear glass is higher than that of the low-e storm windows. However, these results indicate that the SHGC of the low-e storm windows, which is relatively high for a low-e window, still allows for a significant amount of beneficial solar gain and, thus, the impact of pulling blinds is similar between the home with low-e storm windows and the home without. When fully closed, the blinds are expected to decrease the U-factor of the window opening by approximately 0.07-0.13 Btu/hr-ft2-F (Curcija et al. 2013), which should decrease the observed energy use in both homes. However, this impact was not observed to be significant based on the data collected. Since the change in the U-factor of the window opening was the same for both Lab Homes, any differences seen between the Lab Homes would still be caused by the low-e storm windows.

Table 4.4. Average Daily Energy Savings and 95\% Confidence Interval from Low-E Storm Windows Without and With Blinds

\begin{tabular}{lcccc}
\hline \multicolumn{1}{c}{ Operating Scenario } & $\begin{array}{c}\text { Average } \\
\text { Savings } \\
(\text { Wh) }\end{array}$ & $\begin{array}{c}95 \% \\
\text { Confidence } \\
\text { Interval } \\
(\text { Wh) }\end{array}$ & $\begin{array}{c}\text { Average } \\
\text { Savings } \\
(\%)\end{array}$ & $\begin{array}{c}\text { Confidence } \\
\text { Interval } \\
(\%)\end{array}$ \\
\hline Initial 2013 Heating Season, With Storm Windows & 5,404 & 1,678 & 10.3 & 2.3 \\
With Storm Windows in Lab Home B & 14,251 & 2,720 & 10.5 & 1.2 \\
$\begin{array}{l}\text { With Storm Windows in Lab Home B and Blinds Closed } \\
\text { in both Lab Homes }\end{array}$ & 11,819 & 1,707 & 11.1 & 0.9 \\
\hline
\end{tabular}




\subsubsection{Dependence on Outdoor Air Temperature and Solar Insolation}

Savings were also analyzed with respect to daily weather variation, including outdoor air temperature and degree of cloud cover. In both the cooling and the heating season, the magnitude of whole-house energy savings showed significant dependence on these weather attributes.

Energy use of the baseline and experimental homes both show a linear dependence on outdoor air temperature, as shown in Figure 4.2. A relationship between whole-house energy use and the outdoor air temperature is expected because the temperature difference between the inside and outside is the primary driver for HVAC energy use, which accounts for approximately $70 \%$ of whole-house energy use in the measured data. In Figure 4.2, Lab Home A (LHA-blue diamonds) exhibits slightly greater average energy use (higher points) than Lab Home B (LHB-red squares). The data also shows greater temperature dependence of heating season energy use versus cooling season energy use. This is expected because of the lower efficiency of the forced-air electric resistance heating system compared to the heat pump cooling system

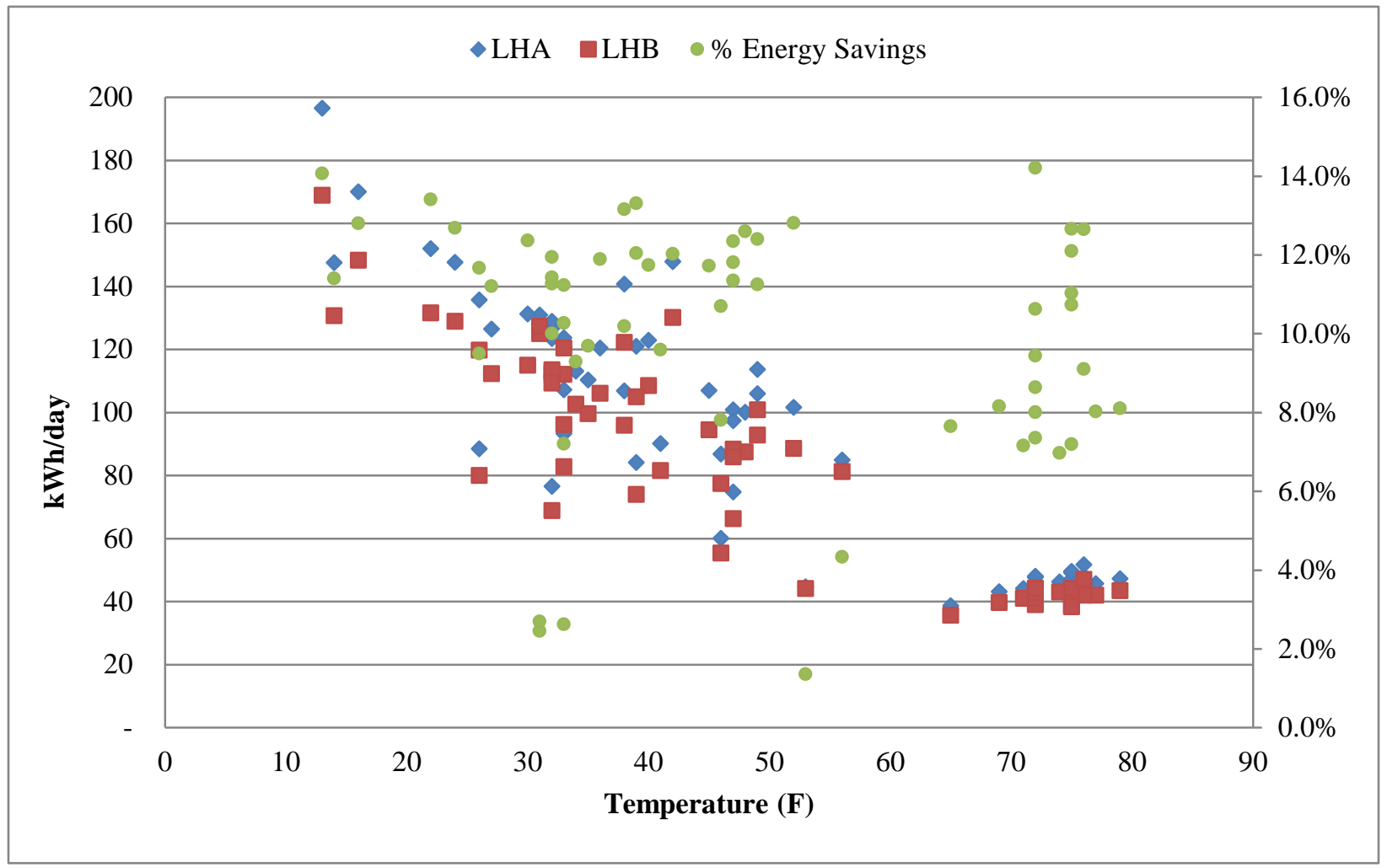

Figure 4.2. Whole-House Energy Use (Wh/d; left axis) and Whole-House Energy Savings (\%; right axis) Versus Outdoor Air Temperature $\left({ }^{\circ} \mathrm{F}\right)$

The whole-house energy use in the heating season also demonstrates a stronger relationship to outdoor air temperature due to the larger temperature differential observed during the 2014 heating season experimental period. With the thermostat set point set at $70^{\circ} \mathrm{F}$ in the cooling and $75^{\circ} \mathrm{F}$ in the heating season, the average difference between the indoor and outdoor daily temperatures was $4.1^{\circ} \mathrm{F}$ and $35.5^{\circ} \mathrm{F}$ during the cooling and heating seasons, respectively. During the heating season, the maximum average daily temperature differential was $62^{\circ} \mathrm{F}$ and the minimum was $13^{\circ} \mathrm{F}$. During the cooling season, the 
maximum average daily temperature differential was $11^{\circ} \mathrm{F}$ and, on the coolest days, minimal or no cooling was needed. Due to the lower temperature differential, as well as the more efficient cooling of the HVAC equipment, the relationship between whole-house energy use and outdoor air temperature was not as dramatic. While not observed in the average daily temperature differentials, large diurnal swings in temperature lead to much more significant temperature differentials in the hottest part of the day, generally the midafternoon, when outdoor temperatures regularly reached over $90^{\circ} \mathrm{F}$.

The effect of solar heat gain on heating system operation is clearly seen in Figure 4.3, which shows the average hourly whole-house energy use in Lab Home A (blue) and Lab Home B (red), as well as interior temperatures in both homes (purple and green lines) and outdoor air temperature (turquoise line) on a clear, sunny day in the winter. Data from January 30, 2014, are shown for the Lab Homes with a $75^{\circ} \mathrm{F}$ set point. The outside average temperature on this day was $41^{\circ} \mathrm{F}$. This graph is illustrative and conclusions shown in it are applicable to other similar sunny days in the heating season.

During the night time, Lab Home B showed lower heating energy use than Lab Home A due to the reduced heat loss resulting from the addition of low-e storm windows. The significant decrease in energy use in the middle of the day is caused by solar heating, which is experienced in both homes, and a higher outdoor air temperature. Interestingly, both homes had similar energy consumption during the daytime under sunny conditions. This can be explained by the fact that the addition of low-e storm windows reduces the SHGC of the primary window somewhat, so the benefit of increased R-value from the storm window is offset by the small decrease in beneficial solar heat gain during the daytime. Also, the HVAC systems operate less frequently during the sunny daytime, which reduces observed energy savings from the low-e storm windows due to overall reduced energy use of the HVAC system during those hours in general. Specifically, some hours in the afternoon no HVAC operation was necessary and, thus, no savings were observed during those hours. However, significant savings are achieved in Lab Home B during the cold night time temperatures, leading to decreased overall daily heating energy when compared to Lab Home A 


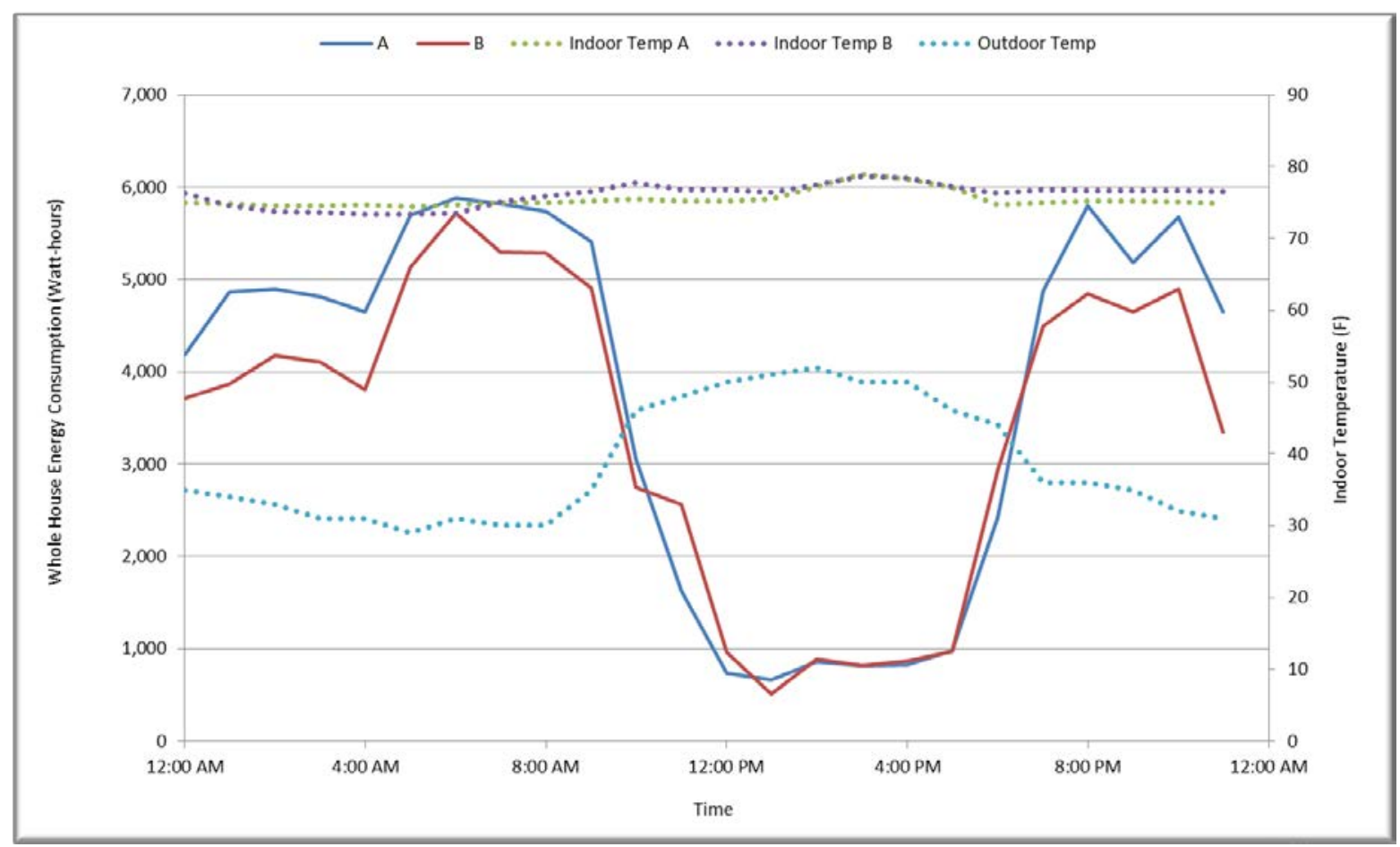

Figure 4.3. Whole-House Energy Use and Indoor Temperature for the Experimental Home (blue and green lines) and the Baseline Home (red and purple lines) on a Cold, Sunny Day

Figure 4.4 compares the cumulative energy use of Lab Home A to that of Lab Home B on the same day (January 30, 2014). A whole-house savings of $9.6 \%$ was achieved on this cold, sunny day (the $45^{\circ}$ red line represents equal energy use by the two homes). The impact of solar heat gain is evident in Figure 4.4 as well. The slope is nearly constant until about 55,000 Wh, which corresponds to 10:00 a.m., indicating that the savings is occurring at a constant rate. At 55,000 Wh the slope of the blue line increases due to the forced-air furnace turning off in Lab Home A with clear-glass windows because solar gains are sufficient to offset most or all of the required heating load, while the furnace has to remain on in Lab Home B for another hour. During this period, the blue line in parallel to the red $45^{\circ}$ line, indicating no energy savings are observed during this period. In the evening, around $70,000 \mathrm{Wh}$, the line returns to the slope it had before 55,000 Wh with both HVAC systems operating and savings continue to accrue for the rest of the day. 


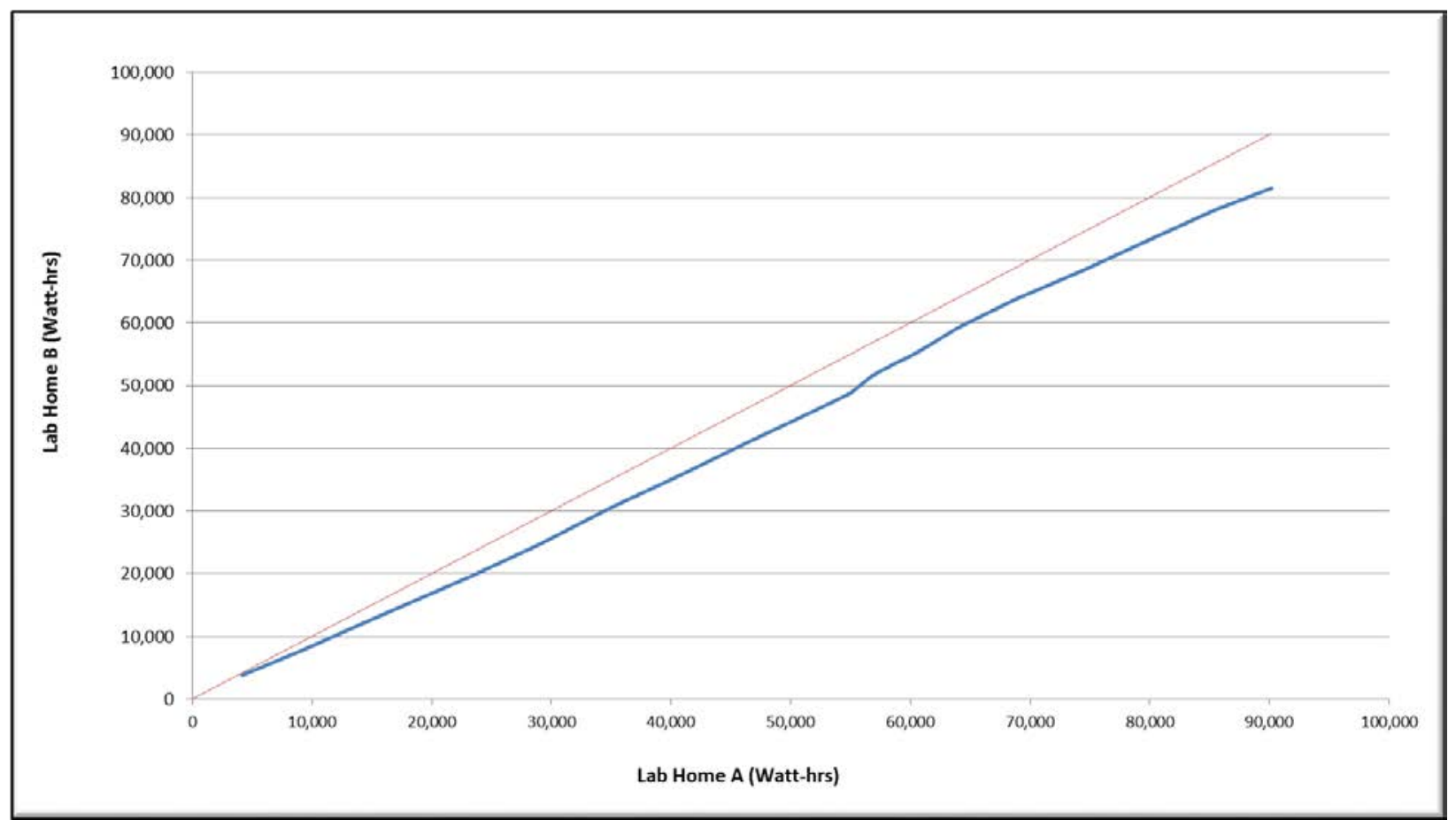

Figure 4.4. Cumulative Energy Use of Lab Home B (Experimental Home) Versus Lab Home A (Baseline Home) on a Cold, Sunny Day.

Figure 4.5 present a similar depiction of the whole-house energy use and indoor temperatures on a representative cold, cloudy day during the heating season (February 6, 2014). During this day, HVAC use is much more consistent throughout the 24 hour period and savings are achieved in Lab Home B consistently throughout the day. Similarly, Figure 4.6 shows a much more uniform slope, indicating a constant rate of energy savings. This is because the solar heat gain through the windows is not present to offset the HVAC energy use in the middle of the day and, thus, reduce or eliminate the observed savings during that period. This can be seen by comparing Figure 4.3, where there is a significant reduction in energy use from 10:00 a.m. to 5:00 p.m., with Figure 4.5, where there is only a slight change in the energy use because there is no sunlight providing solar heat during the day. In addition, the low-e storm windows block somewhat more solar heat gain than the clear-glass windows, which leads to an increase HVAC energy use that mitigates some of the energy savings achieved by the improved U-factor on sunny days.

On cloudy days this effect is not observed and the energy savings are larger. On this cold, cloudy day, Lab Home A consumed 196,525 Wh and Lab Home B consumed 168,882 Wh, a 14.1\% reduction. On the previous sunny day, Lab Home A consumed 90,158 Wh and Lab Home B consumed 81,514 Wh, a $9.1 \%$ reduction. Also note the overall increased whole-house energy use on cloudy days, which is apparent when comparing Figure 4.6 with Figure 4.4. This dramatically reduced overall energy use and percent savings on the sunny day is due to both the higher outside temperature on the sunny day (Figure 4.3 and Figure 4.4) and beneficial solar heat gain offsetting some of the heating requirements. 


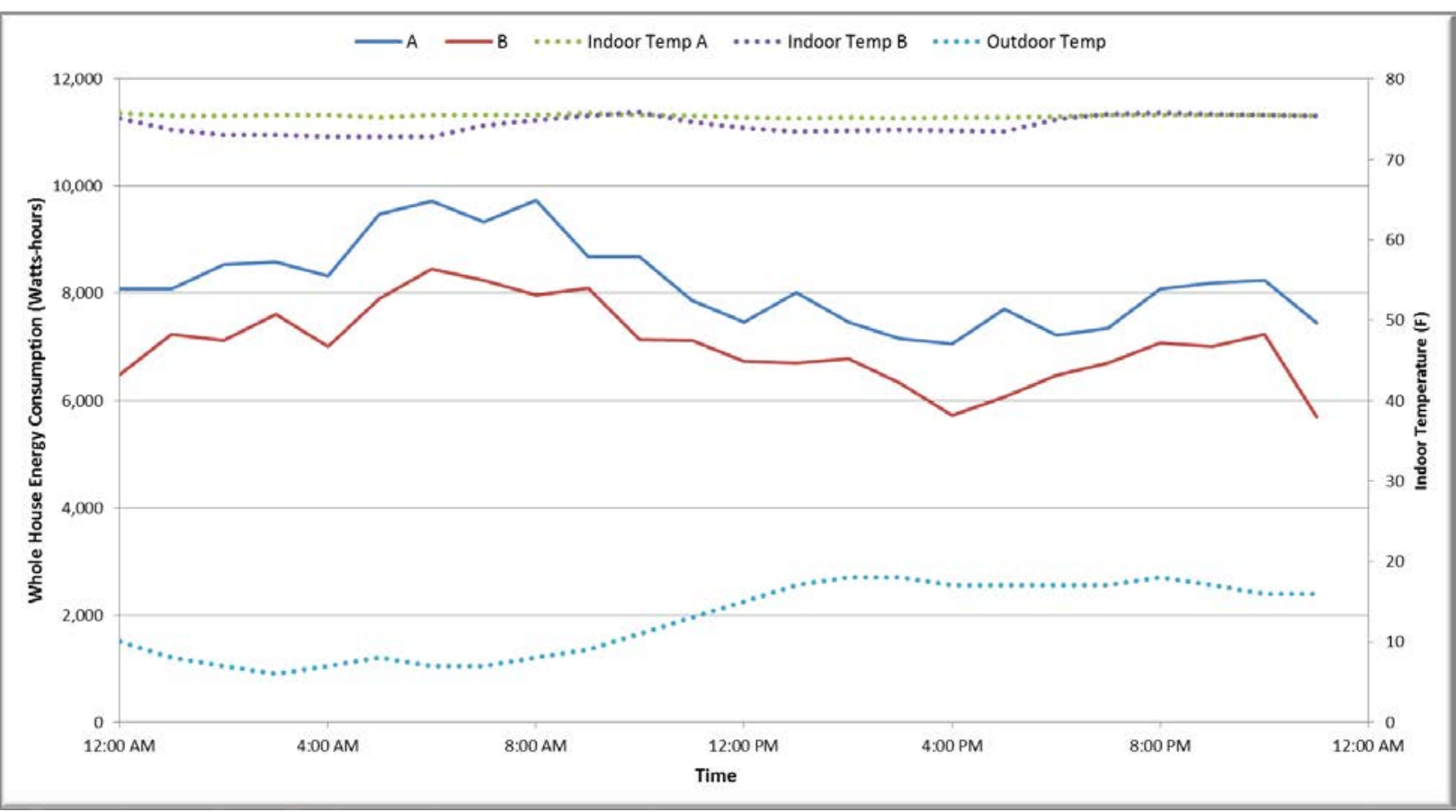

Figure 4.5. Whole-House Energy Use and Indoor Temperature for the Experimental Home (blue and green lines) and the Baseline Home (red and purple lines) on a Cold and Cloudy Day

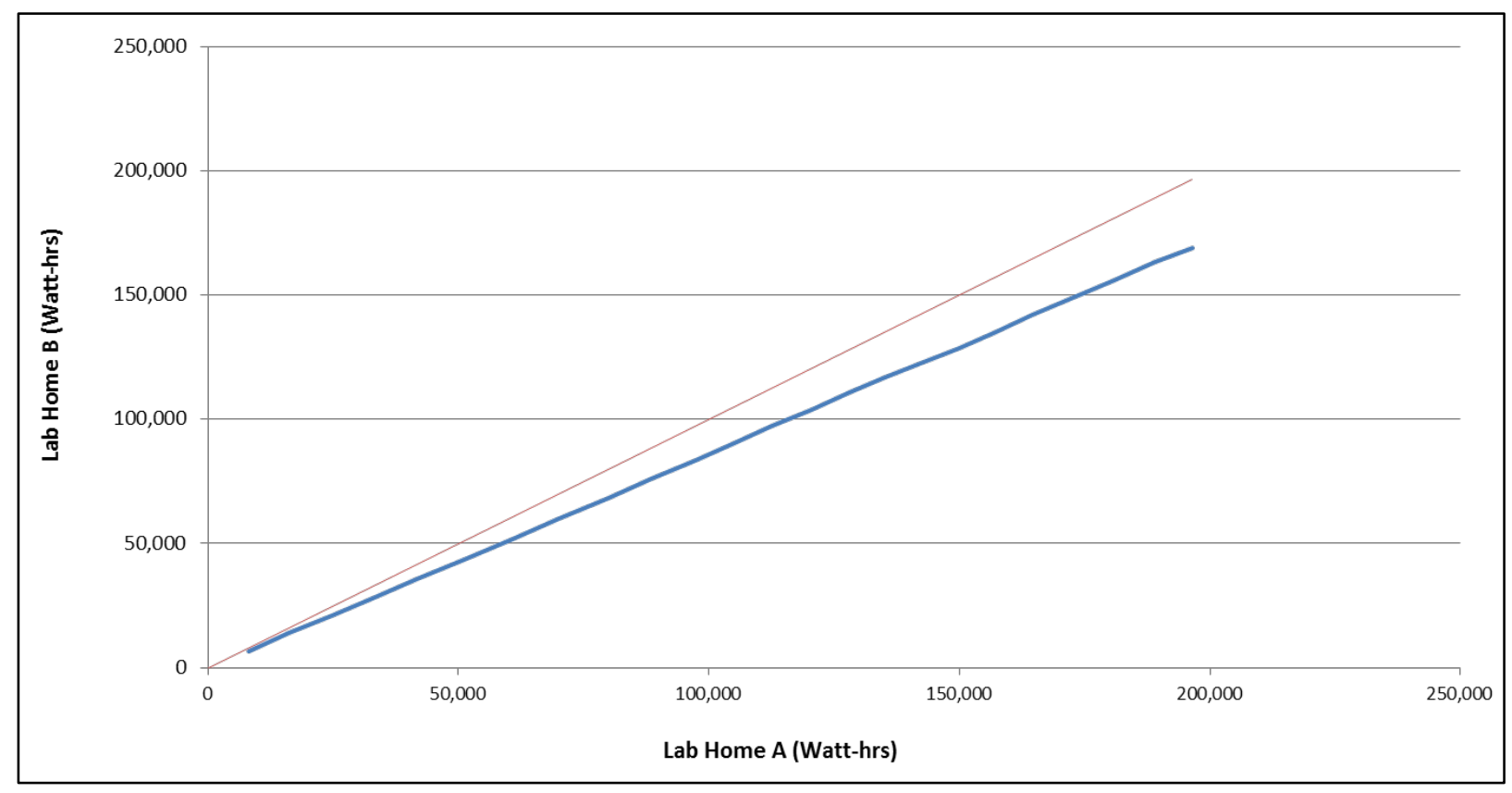

Figure 4.6. Cumulative Energy Use of Lab Home B (Experimental Home) Versus Lab Home A (Baseline Home) on a Cold and Cloudy Day.

The difference in solar insolation transmitted through the glass of the west-facing window in Lab Home A (LHA) and corresponding window in Lab Home B (LHB) can be seen in Figure 4.7. The measured solar insolation transmitted through the window in Lab Home B is $57.7 \pm 3.3 \%$ less than 
through window in Lab Home A. ${ }^{1}$ This measured reduction in transmitted solar insolation is larger than the expected reduction based on modeling presented in section 3.2.1. In the Lab Homes, the low-e storm window was observed to decrease solar gains by $58 \%$ compared to a clear-glass, double-pane window, while the modeling predicted a reduction of only $25 \%$. The difference between expected and measured values could be due to the fact that SHGC is reported at normal incidence, but here data were measured at the real solar angles. Reflectance increases at higher angles and this effect may be more pronounced for the low-e coated glass than clear glass, which may be the cause of the higher than expected reduction in solar insolation through the window. Additionally, SHGC also includes the effect of absorbed solar heat that is then transmitted into the building via conduction, convection, or radiation, whereas this secondary effect is not measured in direct solar insolation measurements.

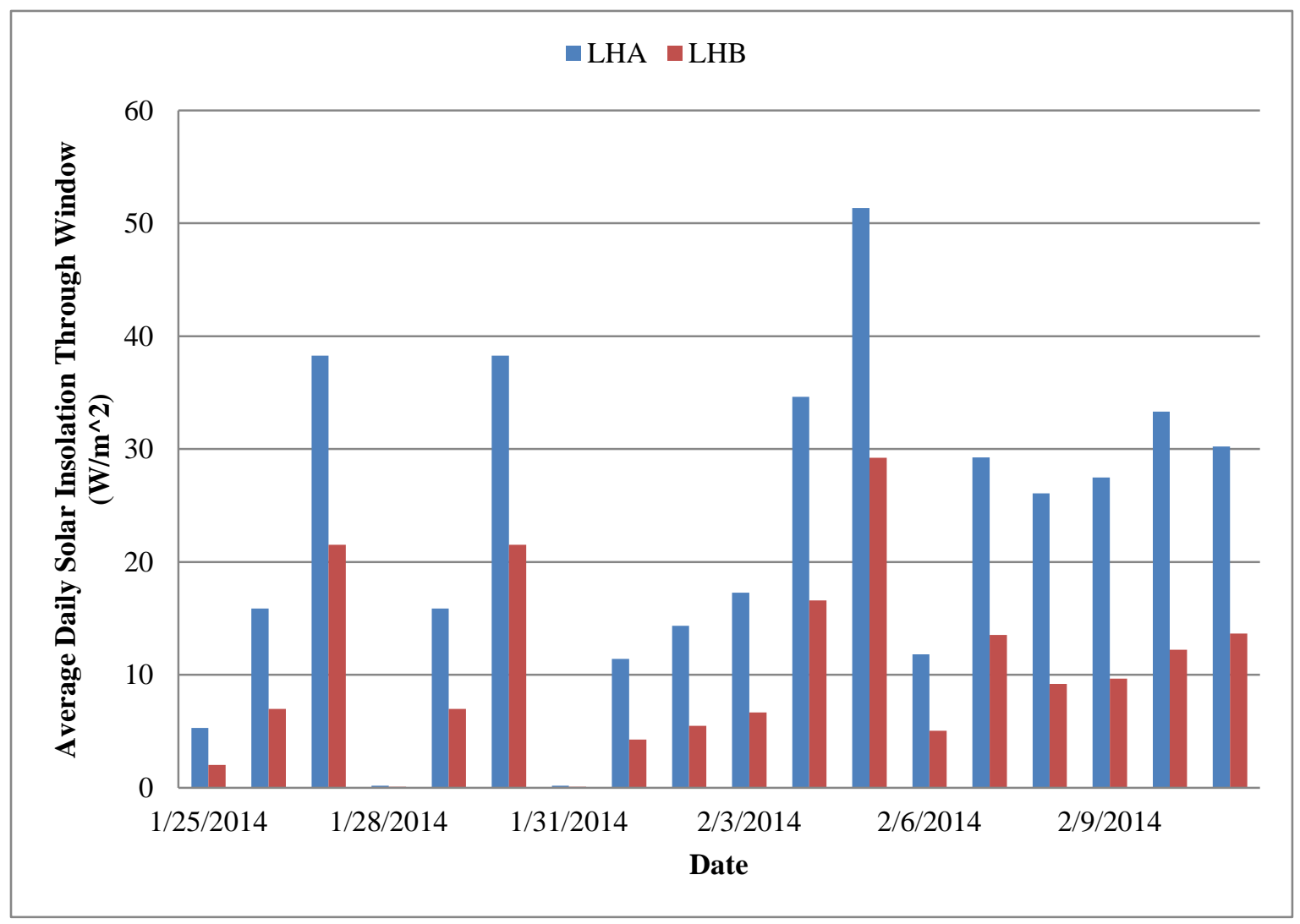

Figure 4.7. Solar Insolation through West-Facing Window during the Heating Season

The dependence of energy use and energy savings on outdoor air temperature and solar insolation in the cooling season is illustrated by comparing two representative days, August 24, 2013 and September 7, 2013. August 24 was much hotter than September 7; the average daily outdoor air temperature was $77^{\circ} \mathrm{F}$ and the maximum temperature in the afternoon was $85^{\circ} \mathrm{F}$ versus an average temperature of $65^{\circ} \mathrm{F}$ and an afternoon maximum temperature of $78^{\circ} \mathrm{F}$. Figure 4.8 shows the whole-house energy use in Lab Home A (blue) and Lab Home B (red), as well as interior temperatures in both homes (purple and green lines) and outdoor air temperature (turquoise line). Whole-house energy use tracks well with outdoor air temperature, as expected, but is reduced in Lab Home B compared to Lab Home A. Unlike the heating season where most of the energy savings occurred during the night, the energy savings occurs during the

\footnotetext{
${ }^{1}$ Note that the solar heat gain measurement reported here is in situ using a pyranometer and does not represent or replicate the measurement of the SHGC calculation from computer models used in NFRC window rating.
} 
day when the temperature difference between inside and outside and solar gains are greatest. As one can see in Figure 4.9 the energy use in both homes is approximately the same until around 15,000 Wh, which corresponds to around 9:00 A.M., when the outside temperature begins increasing dramatically and the sun is rising higher in the sky. The slope of the line changes again around 44,000 Wh, which corresponds to around 10:00 P.M., at which time the sun has set and the outdoor temperature is cooling down and approaching the indoor temperature. On this hot, sunny day, Lab Home A used 47,260 Wh of energy and Lab Home B used 43,430 Wh, a savings of 8.1\% in Lab Home B.

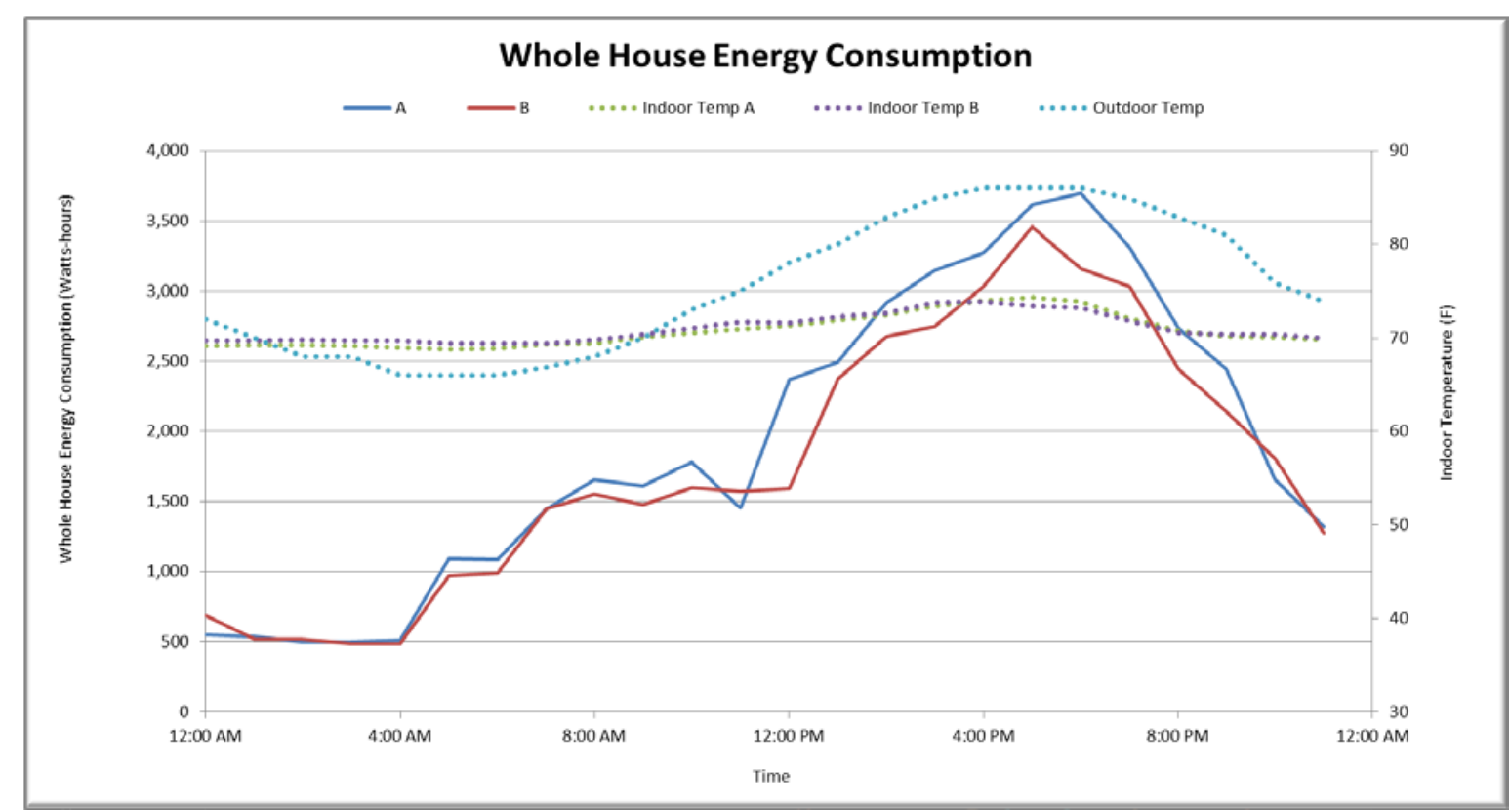

Figure 4.8. Cumulative Energy Use of Lab Home B (Experimental Home) Versus Lab Home a (Baseline Home) on a Hot Day. 


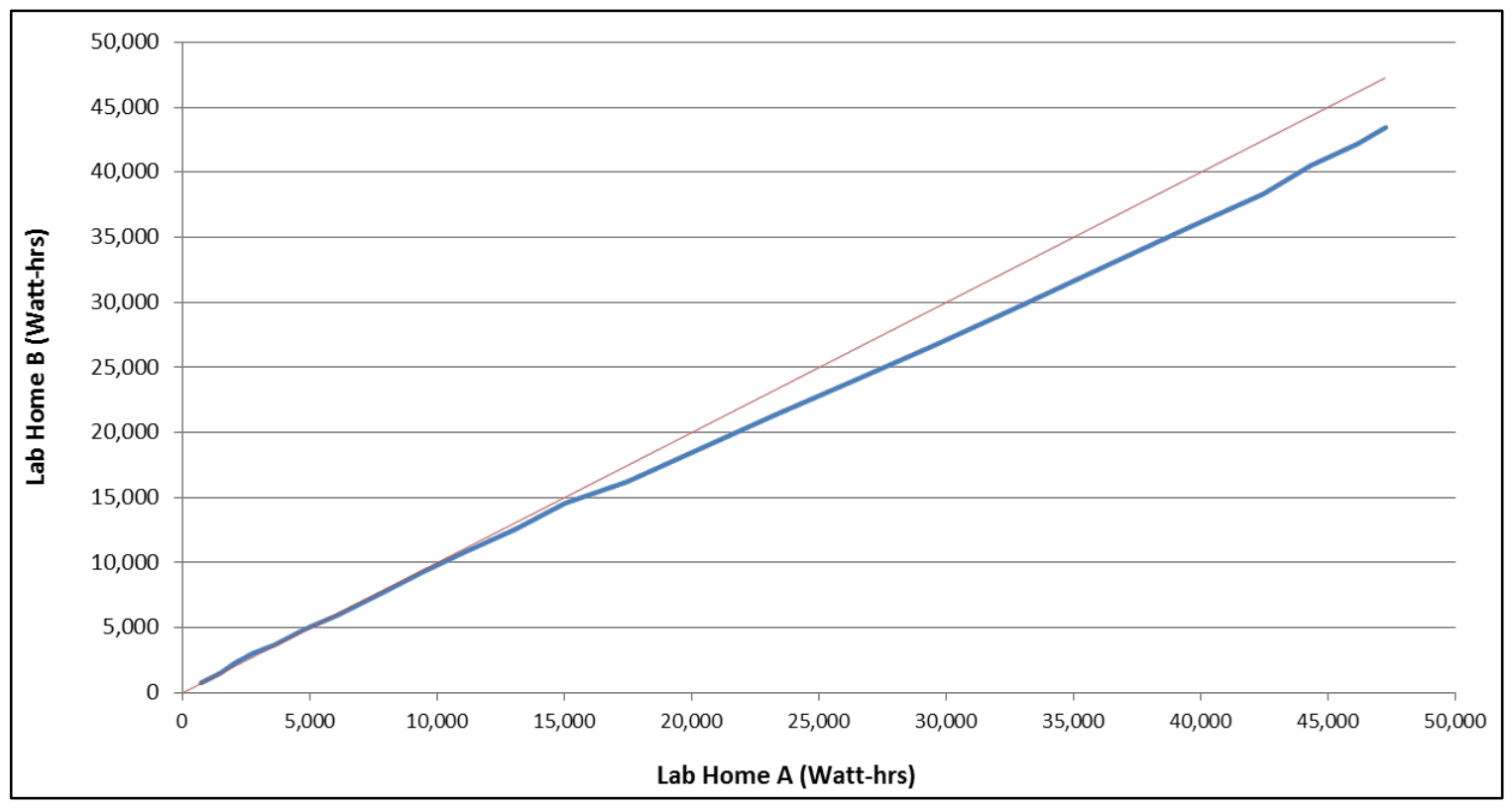

Figure 4.9. Cumulative Energy Use of Lab Home B (Experimental Home) Versus Lab Home A (Baseline Home) on a Hot Day.

The energy use and savings on August 24 is compared to a day with a milder daily, September 7, to describe the impact of outdoor air temperature on the observed trends in energy use and savings.. Because heat transfer, and thus HVAC energy use in a house, is dependent on the difference between indoor and outdoor temperatures, significantly greater savings are observed on hotter days when more energy is used by the cooling system. A cumulative energy-use plot of whole-house energy use in Lab Home B versus Lab Home A (Figure 4.10) shows a profile similar to Figure 4.9 but when comparing the $\mathrm{x}$-axes of the two figures the total energy use in the Lab Homes on a mild day is about 20 percent less than the energy use on a hot day. Just like on the hot day, the energy savings occurs during the day when the sun is out and there is a larger difference in outdoor and indoor temperature and direct solar gains. On September 7, Lab Home A used 38,593 Wh of energy and Lab Home B used 34,732 Wh, resulting in total daily energy savings of $7.6 \%$ in Lab Home $B$. The small spike in energy use in Lab Home A in Figure 4.11 at 6:00 P.M. is due to HVAC system cycling on and off. The peak is prominent in Lab Home A (around 8:00 P.M.) primarily due to the relatively low amount of overall energy use on this mild day. 


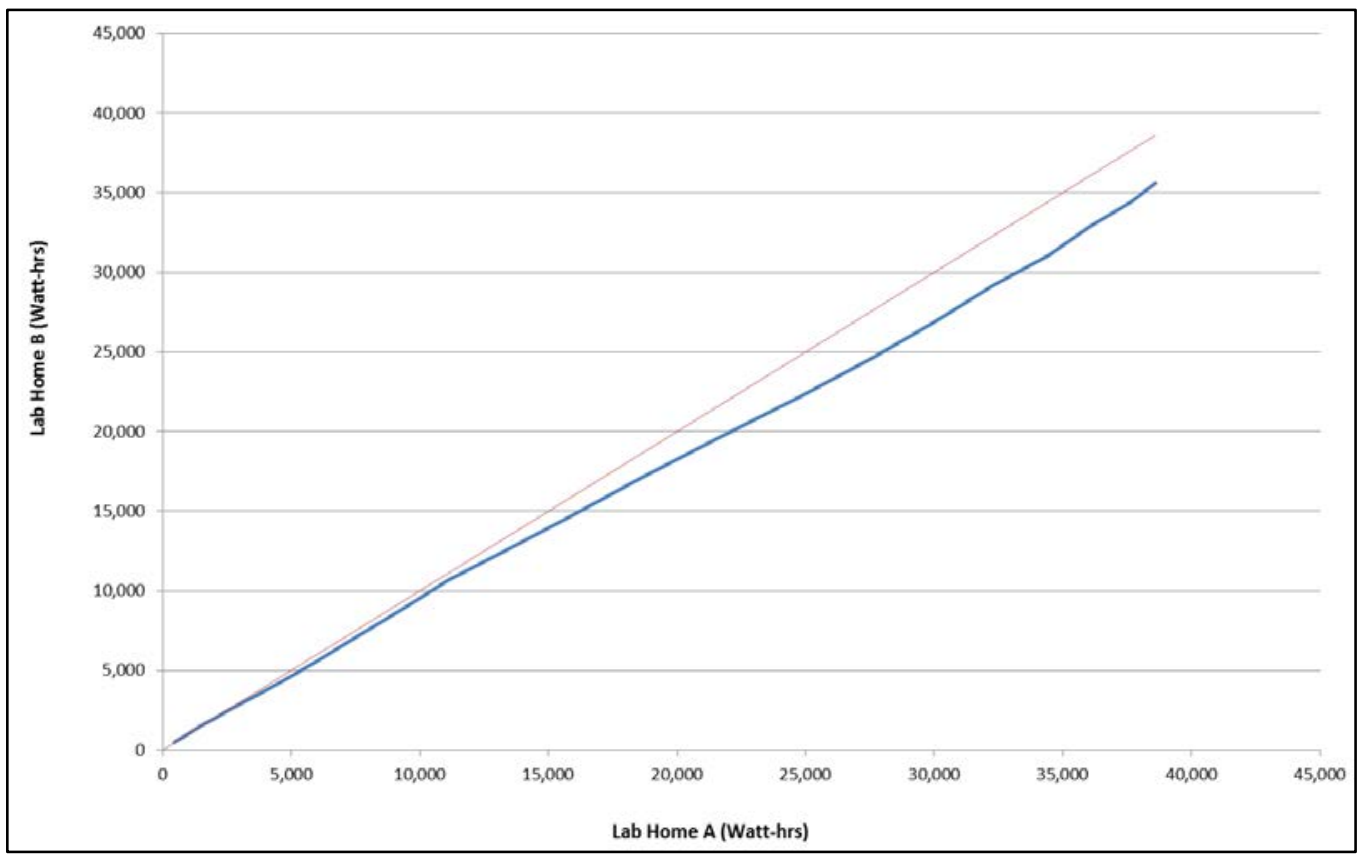

Figure 4.10. Cumulative Energy Use of Lab Home B (Experimental Home) Versus Lab Home A (Baseline Home) on a Milder Day (daily average outdoor air temperature of $65^{\circ} \mathrm{F}$ ).

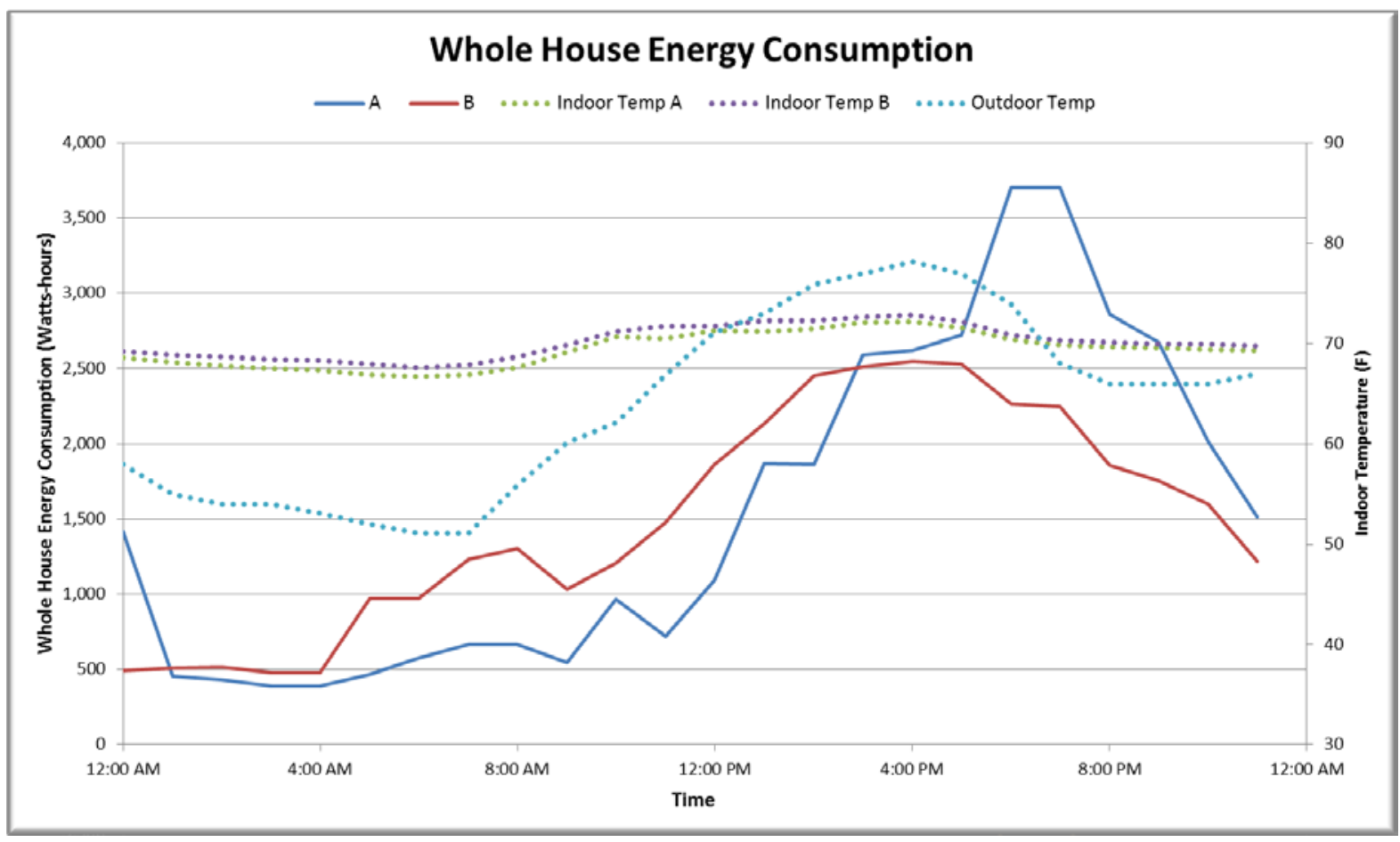

Figure 4.11. Hourly Average Whole-House Energy Use and Indoor Temperature for the Experimental Home (red and purple lines) and the Baseline Home (blue and green lines) and Outdoor Air Temperature on a Mild Day 


\subsection{Average Annual Savings}

Measured data were extrapolated to estimate annual energy savings based on the heating degree days (HDD - base $65^{\circ} \mathrm{F}$ ) and cooling degree days (CDD - base $65^{\circ} \mathrm{F}$ ). Energy savings, in kilowatt-hours, were scaled based on HDD and then extrapolated to total annual heating season savings based on the number of HDD in a typical year (TMY3 file) in Pasco, Washington. A similar analysis was done for cooling savings measured during the summer experimental period and typical CDD in the TMY3 file. This calculation is shown in the following equations:

$$
\begin{aligned}
& \text { Annual Heating Savings }(k W h)=\frac{\text { Measured Savings } \text { Heating Test Period }(k W h)}{H D D_{\text {Heating Test Period }}\left({ }^{\circ} \mathrm{F}\right)} \times H_{D D} D_{T M Y}\left({ }^{\circ} \mathrm{F}\right) \\
& \text { Annual Cooling Savings }(k W h)=\frac{\text { Measured Savings Cooling Test Period }(k W h)}{C D D_{\text {Cooling Test Period }}\left({ }^{\circ} \mathrm{F}\right)} \times C D D_{T M Y 3}\left({ }^{\circ} \mathrm{F}\right)
\end{aligned}
$$

Annual Savings $(k W h)=$ Annual Heating Savings $(k W h)+$ Annual Cooling Savings $(k W h)$

The sum of the measured savings, $256.5 \mathrm{kWh} / \mathrm{d}$, is divided by the total HDD observed in the experimental period (660 HDD) and that value is multiplied by the annual HDD in Pasco, Washington (4916 HDD) to estimate the annual heating savings $(1,910.7 \mathrm{kWh} / \mathrm{yr})$. The same method was used to calculate the annual cooling savings and these values are shown in Table 4.5. Summing the estimated annualized heating and cooling savings gives a total annual savings of 2,216 $\pm 31.3 \mathrm{kWh}$, or $10.1 \pm 1.4 \%$, based on the measured data.

\begin{tabular}{|c|c|c|c|c|c|}
\hline & $\begin{array}{c}\text { Measured } \\
\text { Savings (kWh) }\end{array}$ & $\begin{array}{r}\text { Measured } \\
\text { HDD/CDD }\end{array}$ & $\begin{array}{c}\text { Energy } \\
\text { Savings per } \\
\text { Degree Day } \\
\text { (kWh/DD) }\end{array}$ & $\begin{array}{c}\text { TMY } \\
\text { HDD/CDD }^{1} \\
\end{array}$ & $\begin{array}{c}\text { Calculated } \\
\text { Annual Energy } \\
\text { Savings (kWh) }\end{array}$ \\
\hline Heating Season & 256.5 & 660 & 0.389 & 4,916 & $1,910.7$ \\
\hline Cooling Season & 40.5 & 94 & 0.431 & 708 & 305.2 \\
\hline Total & & & & & 2,215.9 \\
\hline
\end{tabular}

Table 4.5. Annual Energy Savings Generated by Exterior Low-E Storm Windows

\subsection{Cost Effectiveness of Exterior Low-E Storm Windows}

The energy savings achieved by exterior low-e storm windows in the PNNL Lab Homes have demonstrated the potential of this technology to significantly improve the energy efficiency of homes. However, the market viability of any energy-efficiency measure will typically depend on the energy saving potential relative to the cost to purchase and install the measure.

To describe the cost effectiveness of low-e storm windows, a simple payback period analysis is performed, with no discounting. This simple calculation provides a straightforward comparison of the energy savings and capital costs for the energy-efficiency measure. For the calculation of payback

\footnotetext{
${ }^{1}$ HDD and CDD data retrieved from NREL's National Solar Radiation Data Base. Can be accessed at http://rredc.nrel.gov/solar/old_data/nsrdb/1991-2005/tmy3/by_state_and_city.html\#W
} 
period, annual energy savings reported in Section 4.4 are used. The estimated annual savings extrapolated based on the measured data and typical HDD and CDD are 2,216 kWh/yr or $10.1 \%$. The annual utility bill cost savings are determined by multiplying the annual energy savings in $\mathrm{kWh}$ by the 2013 national average cost of electricity estimated at 12.12 $\$ / \mathrm{kWh}$ (EIA 2014). This results in an annual savings of $\$ 269 / \mathrm{yr}$.

The window manufacturer (i.e., Larson Manufacturing) estimated the cost of the low-e storm windows for the Lab Homes to be approximately \$1,900 (i.e., \$9.69/ $/ \mathrm{ft}^{2}$ ) for $196 \mathrm{ft}^{2}$ of window area. The cost per square foot for the Lab Homes is slightly higher than the typical storm window costs per square foot at home improvement stores, which ranges from $\$ 6.91$ to $\$ 8.08 / \mathrm{ft}^{2}$ because several of the windows for the Lab Homes had to be custom made and the two low-e sliding glass doors were more expensive than typical low-e storm windows. ${ }^{1}$ Using the median cost for this range (i.e., \$8.30/ft2) would result in a lower total cost of $\$ 1,627$ and would result in a 6-year payback period based on the annual savings of $\$ 269$ (see Table 4.6). Using high and low estimates for the cost of the low-e storm windows (shown in Table 4.6), the payback period ranges from 5 to 7 years. Note that no installation costs are included in this analysis, as low-e storm windows are designed to be self-installed by the homeowner-in most cases - and professional installation is not required.

Table 4.6. Cost-Effectiveness Calculations for Low-E- Storm Windows

\begin{tabular}{ccccc}
\hline Window Area (sf) & Cost $(\$ /$ sf) & Total Cost & Annual Savings & $\begin{array}{c}\text { Simple Payback } \\
\text { (Years) }\end{array}$ \\
\hline 196 & 6.91 & $\$ 1,354$ & $\$ 269$ & 5.03 \\
196 & 8.30 & $\$ 1,627$ & $\$ 269$ & 6.05 \\
196 & 9.69 & $\$ 1,900$ & $\$ 269$ & 7.06 \\
\hline
\end{tabular}

\subsection{Interior Temperature Distributions}

The exterior storm windows also had some impact on indoor temperature distribution within the homes. Indoor temperatures for every room in each home, the average interior temperature, and the thermostat set point are shown in Figure 4.12 and Figure 4.13 for the heating season and cooling season, respectively. Comparing the temperature profiles of the Lab Homes on a sunny day in the heating season (Figure 4.12), one can see that Lab Home B experiences a smaller swing in temperature in the afternoon (hours 13 to 18) when the home is experiencing the most solar heat gain.

Figure 4.13 shows overcooling occurring in some rooms in both homes during the cooling season, probably due to the location of the thermostat (in the hallway adjacent to the kitchen in both homes). Temperatures as low as $62^{\circ} \mathrm{F}$ are observed in both Lab Homes A and B in the rooms closest to the air handler - the bathroom, west bedroom, and east bedroom receive the most air because of shorter duct runs.

\footnotetext{
${ }^{1}$ Costs for Larson low-e storm windows were retrieved from Lowe’s (https://www.lowes.com) and Menards (https://www.menards.com/)
} 


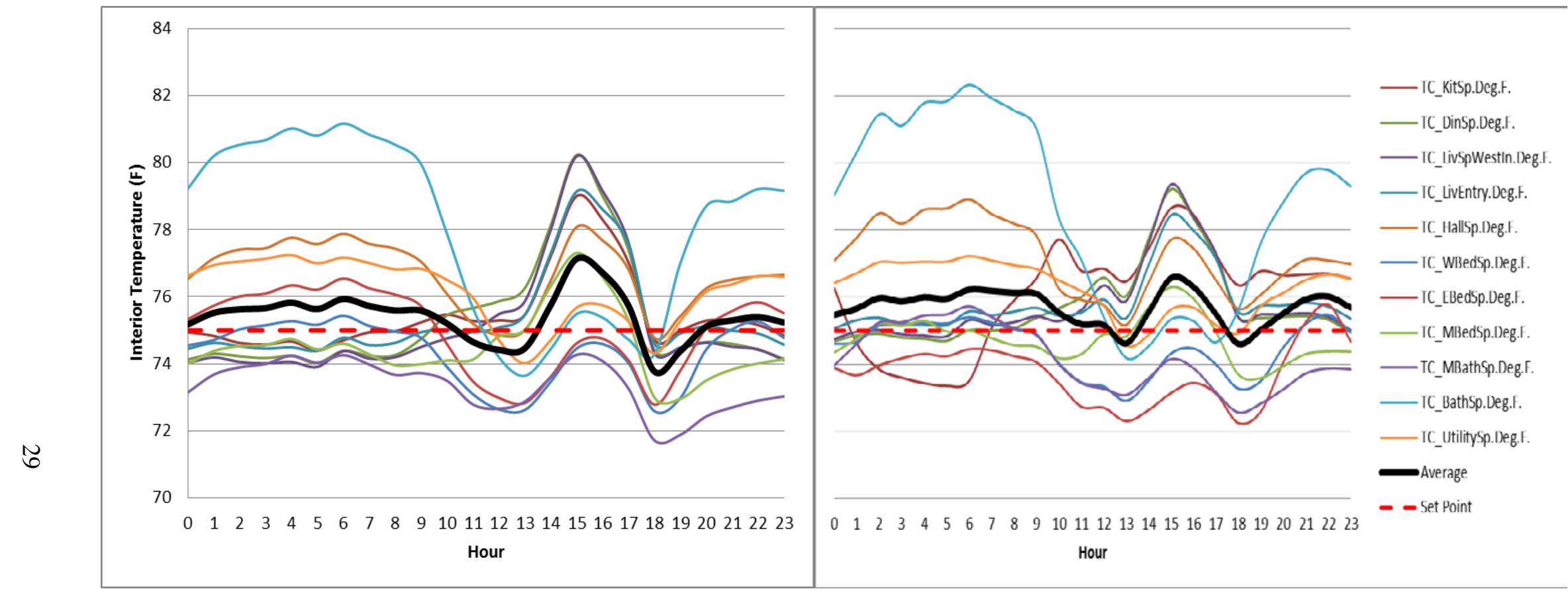

Figure 4.12. Interior Temperature Distribution for Lab Home A (left) and Lab Home B (right) on a Sunny Day in the Heating Season 

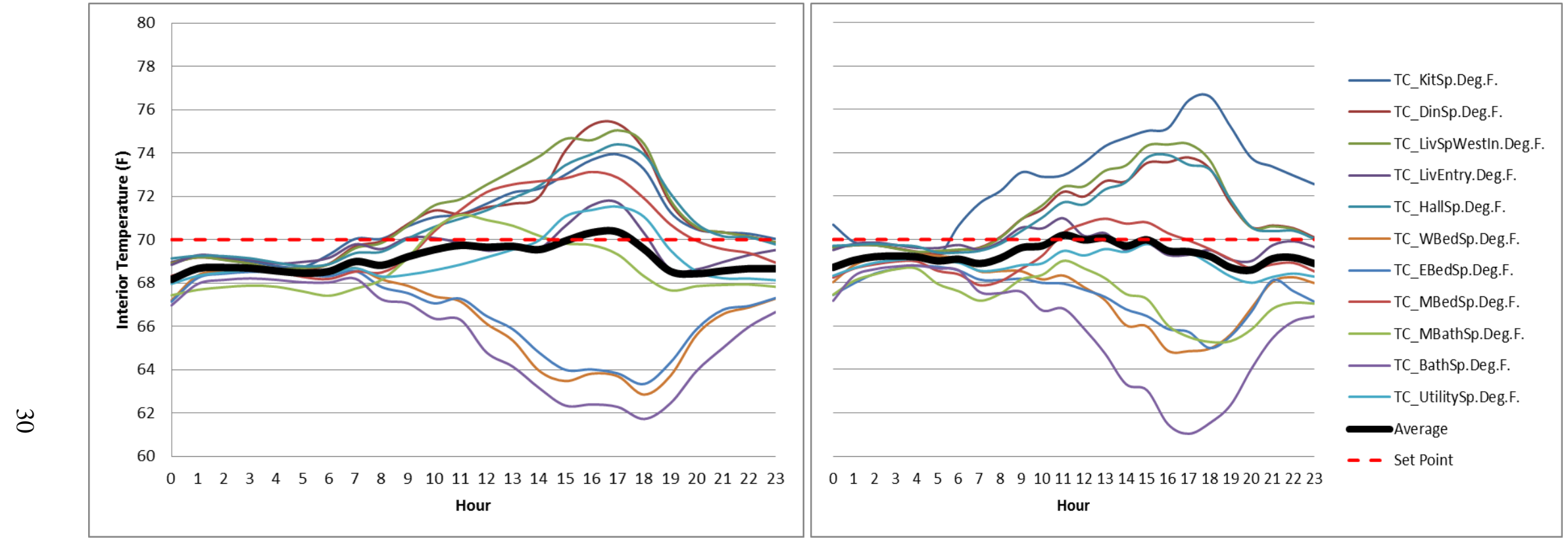

Figure 4.13. Interior Temperature Distribution for Lab Home A (left) and Lab Home B (right) on a Hot Sunny Day 


\subsection{Thermal Comfort}

Mean radiant temperature (MRT) was measured in two rooms in both Lab Homes. The MRT sensors are located in the master bedroom and in the northwest corner of the living room. MRT is a measured proxy for thermal comfort/discomfort resulting from the radiant heat exchange between an occupant (a body) and surrounding surface temperatures, such as the surface temperature of a window or a wall. Figure 5.1 and Figure 5.2 show the MRT in both Lab Homes in the winter and summer, respectively. In the winter during the night when the radiant heat loss is the greatest, the average MRT of both the master bedroom and the living room in Lab Home B are on average $1.1^{\circ} \mathrm{F}$ warmer than in Lab Home A. The MRT in Lab Home B is more consistent in both the winter and summer and does not experience swings in temperature that are as large as those experienced in Lab Home A, leading to potentially higher comfort levels for occupants with the use of low-e storm windows.

In the left graph of Figure 5.2, there is a significant increase in MRT in Lab Home A from about 4:00 to 8:00 in the afternoon. This peak in MRT is a regular occurrence in the cooling season in Lab Home A. This spike in MRT occurs later in the afternoon when sunlight is shining through the window next to the MRT sensor. The sunlight coming through the window of Lab Home A would contain more energy, due to the higher SHGC of the windows without low-e storm windows covering them, and would thus heat up the surface of the MRT sensor and the area around the MRT sensor that the sunlight is striking. This more consistent MRT could be indicative of higher levels of comfort for occupants with the use of low-e storm windows. 

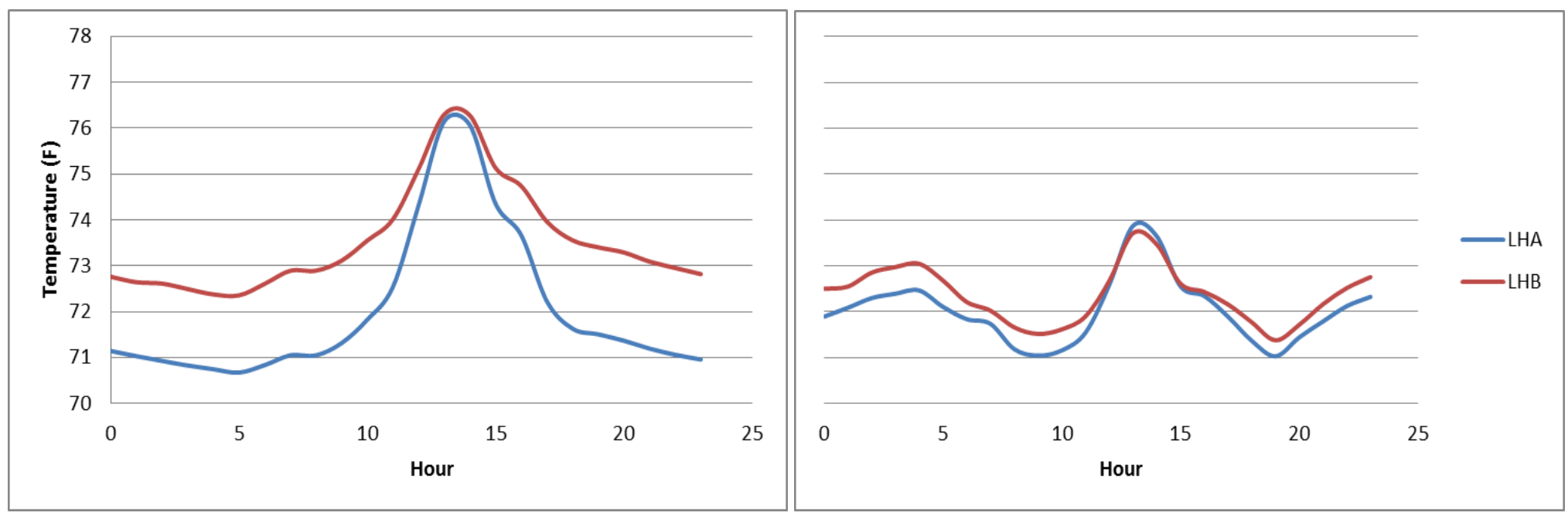

Figure 5.1. Daily Mean Radiant Temperature Profile of Lab Homes A and B (blue line and red line, respectively) in the Living Room (left) and Master Bedroom (right) during the Heating Season
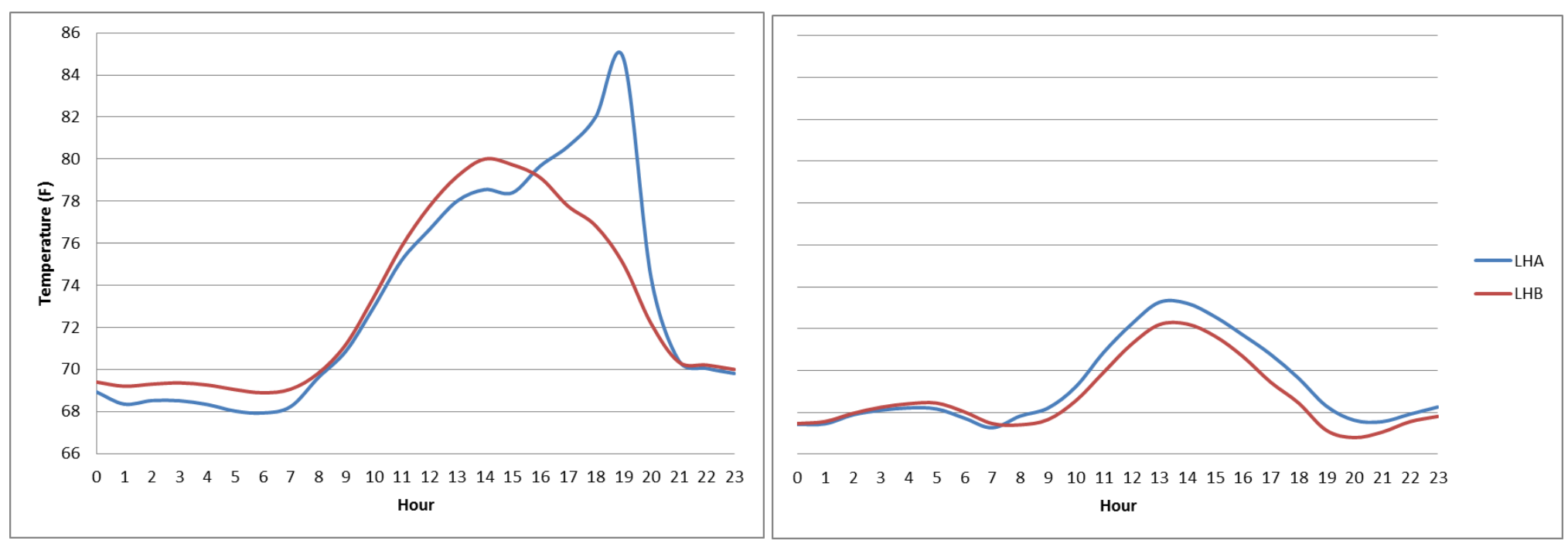

Figure 5.2. Daily Mean Radiant Temperature Profile of Lab Homes A and B (blue line and red line, respectively) in the Living Room (left) and Master Bedroom (right) during the Cooling Season 


\subsection{Interior Low-E Storm Windows}

In addition to evaluating the energy-saving potential of exterior low-e storm windows, this project performed a preliminary comparison and evaluation of low-e interior storm windows / panels ${ }^{1}$, which are installed on the inside of the home instead of the outside. Installation from the interior can be particularly advantageous when the primary windows are outswing casement windows, and in taller apartment buildings where installation from the exterior is difficult. Other than that, interior storm windows serve much the same purpose of exterior storm windows and, thus, similar results are expected. To evaluate low-e interior storm windows, low-e interior panels from Quanta Technologies were installed in Lab Home A on March 9, 2014, and data were collected for 16 days. Details on a typical installation process for interior storm windows are given in Appendix B.

Because the low-e exterior storm windows were still installed in Lab Home B, this experiment compared the performance of the interior low-e storm window to that of the exterior storm window, both installed over the same primary windows. However, interior low-e storm doors are not available for sliding glass doors and, thus, there were no low-e storm sliding glass doors installed over the sliding glass doors in Lab Home A. Ideally, exterior low-e storm doors would also have been installed Lab Home A to allow a more direct comparison of the exterior and interior low-e storm windows, but these were not available for this short test timeframe. The two sliding glass doors, with a surface area of $80 \mathrm{ft}^{2}$, compose $40.9 \%$ of the total window area of a Lab Home. This lack of low-e sliding glass doors on Lab Home A would be expected to reduce the magnitude of the savings when compared with the savings derived from the exterior storm windows. The savings derived from the interior low-e storm windows installed is $33.3 \%$ lower than the savings from the exterior low-e storm windows, which corresponds well to the $40.9 \%$ reduction in retrofitted window area. Therefore, we hypothesize that the savings from interior storm windows are roughly equivalent to those achieved by exterior storm windows on a per square-foot basis. The energy savings generated are mostly due to the improved U-factor of the windows, so the savings would be linearly related to the window area that is covered because both homes are experiencing the same outdoor temperature. To calculate the savings associated with the interior storm windows a somewhat more complicated analysis is needed because there is no longer a control (primary clear, glass windows with no low-e storm windows) with which to compare the energy use. To calculate the savings derived from using interior storm windows, the energy use in Lab Home B was manipulated to determine the "estimated" whole-house energy use if Lab Home B had only clear-glass primary windows installed to act as a control, or baseline, to which we can compare the measured energy use of Lab Home A with interior low-e panels installed. This way, the confounding weather and occupancy effects are still controlled against and the benefits of a side-by-side evaluation are retained. To derive the daily energy consumption of Lab Home B with no storm windows installed, the average savings per HDD in Lab Home B, calculated from previously collected data, is multiplied by the number of HDD experienced on that day and that number is added to the daily energy consumption in Lab Home B. Thus, by adding the energy saved by the exterior storm windows to the energy actually used in Lab Home B the estimated consumption of the baseline home without the exterior storm windows is calculated. By this method, the low-e interior storm windows are estimated to save an average of $4975 \mathrm{Wh} / \mathrm{d}$ (Table 6.1) during the heating season with an average outdoor air temperature of $47^{\circ} \mathrm{F}$.

\footnotetext{
${ }^{1}$ Interior low-e storm windows are often also referred to as low-e panels.
} 
Table 6.1. Average Daily Energy Savings and 95\% Confidence Interval from Low-E Interior Storm Windows

\begin{tabular}{|c|c|c|c|c|}
\hline Operating Scenario & $\begin{array}{l}\text { Average } \\
\text { Savings } \\
\text { (Wh) }\end{array}$ & $\begin{array}{l}\text { 95\% Confidence } \\
\text { Interval } \\
\text { (Wh) }\end{array}$ & $\begin{array}{l}\text { Average } \\
\text { Savings } \\
(\%)\end{array}$ & $\begin{array}{l}\text { 95\% Confidence } \\
\text { Interval } \\
(\%)\end{array}$ \\
\hline $\begin{array}{l}\text { With Interior Low-E Storm Windows (but no } \\
\text { storm doors on the sliding glass doors) }\end{array}$ & 4,975 & 1,188 & 7.0 & 1.53 \\
\hline
\end{tabular}

Overall, this is only a preliminary study of low-e interior storm windows with a much shorter testing period and higher outdoor temperatures than with the exterior storm windows, so additional testing is required to provide more robust estimates of energy savings. Nonetheless, similar to exterior low-e storm windows, interior low-e storm windows show the potential for significant energy savings in improving the performance of existing windows. 


\subsection{Conclusions}

This experiment used two side-by-side Lab Homes on the PNNL campus to measure the potential energy savings and thermal comfort impacts of exterior low-e storm windows (and patio doors) in the Experimental Home compared to the baseline home equipped with standard double-pane clear-glass, aluminum-frame windows and sliding clear-glass patio doors. The windows in the baseline home are representative of many existing homes across the Pacific Northwest and much of the United States. Testing was conducted during the 2013-2014 winter heating and summer cooling seasons and the collected data showed that exterior low-e storm windows result in a $10.5 \pm 1.2 \%$ and $8.0 \pm 0.9 \%$ reduction in whole-house energy use during the heating and cooling season, respectively. These savings resulted in a simple payback period between 5 and 7 years, using low and high estimates for the price of the exterior storm windows, which suggest low-e storm windows may be a cost-effective retrofit option for many existing homes in the Pacific Northwest and, potentially, the nation. In addition to energy savings, the mean radiant temperatures of the home interior were warmer and showed less temperature swing during the heating season for the Lab Home with low-e storm windows, which indicates that the use of low-e storm windows could lead to potentially higher comfort levels for occupants.

The experimental protocol also included limited evaluation of interior low-e storm windows during the heating season only. Based on the measured data, the interior low-e storm windows were found to have a similar level of energy savings as the exterior low-e storm windows. However, additional testing of the interior low-e storm windows in the Lab Homes should also be undertaken. This further testing would feature the interior storm windows installed in the Experimental Home and the baseline home operating without any alterations and encompass the heating and cooling season, to generate more robust data to characterize the energy and thermal comfort performance of these interior products.

This experiment also evaluated the impact of blinds on the energy savings resulting from exterior low-e storm windows and found that the blinds further decreased HVAC energy use in the cooling season, due to reduced solar gains, but did not significantly impact the percentage savings from the low-e storm windows in the heating season when the blinds were drawn uniformly in both homes. Additional experiments could further evaluate the performance of blinds or other window attachment technologies as individual energy-efficiency measures in the same, detailed manner.

This evaluation has added to the body of knowledge about low-e storm windows by presenting measureable energy savings in a controlled setting. Results from this study clearly show that low-e storm windows are viable energy retrofits in single-family residences and should be explored further across a variety of building types and climate zones. 


\subsection{References}

AAMA (American Architectural Manufacturers Association). 2012. "Window and Door Sales to Accelerate Next Year.” Window \& Door Magazine. Volume 20, Number 4, June/July 2012, - American Architectural Manufacturers Association.

Cort KA. 2013. Low-E Storm Windows: Market Assessment and Pathways to Market Transformation. PNNL-22565, Pacific Northwest National Laboratory, Richland, Washington.

Culp TD, and KA Cort. 2013. Database of Low-E Storm Window Energy Performance across U.S. Climate Zones (Task ET-WIN-PNNL-FY13-01_5.3). PNNL-22864, Pacific Northwest National Laboratory, Richland, Washington.

Culp TD, SC Drumheller, and J Wiehagen. 2013. Low-E Retrofit Demonstration and Education Program. Final Report, U.S. DOE project \#DE-E E0004015, Quanta Technologies, Malvern, Pennsylvania.

Curcija DC, M Yazdanian, et al. 2013. Energy Savings from Window Attachments. Prepared for U.S. Department of Energy under DOE EERE award \#DE-FOA-0001000. Lawrence Berkeley National Laboratory, Berkeley, California

Drumheller SC, C Kohler, and S Minen. 2007. Field Evaluation of Low-e Storm Windows. LBNL 1940E, Lawrence Berkley National Laboratory, Berkeley, California.

Energy Information Administration (EIA). 2014. Electric Power Monthly. Available at: http://www.eia.gov/electricity/monthly/epm_table_grapher.cfm?t=epmt_5_3

Huang, J, J Hanford, et al. 1999. Residential Heating and Cooling Loads Component Analysis. LBNL44636, Building Technologies Department, Lawrence Berkeley National Laboratory, Berkeley, California.

Klems JH. 2003. “Measured Winter Performance of Storm Windows.” ASHRAE Transactions 109(2), Paper KC-03-12-1, Lawrence Berkeley National Laboratory, Berkeley, California.

Krigger J and B Van der Meer. 2011. Weatherization Standards and Field Guide for Pennsylvania. Published for the U.S. Department of Energy Weatherization Assistance Program and the Pennsylvania Department of Community, Economic Development, and Office of Energy Conservation and Weatherization, Harrisburg, Pennsylvania.

Parker GB, TS Mapes, and WJ Zalis. 2013. Highly Insulating Windows Volume Purchase Program Final Report. PNNL-22183, DOE/EE-0884, Pacific Northwest National Laboratory, Richland, Washington.

Quanta Technologies. 2013. 2012-13 Quarterly Reports prepared for U.S. Department of Energy under DOE EERE award \#DE-EE0004015, Malvern, Pennsylvania. 
Widder SW, MC Baechler, et al. 2012. Side-by-Side Field Evaluation of Highly Insulating Windows in the PNNL Lab Homes. PNNL-21678, Pacific Northwest National Laboratory, Richland, Washington.

Zalis W, et al. 2010 Evaluation of Low-E Storm and R-5 Windows for Inclusion in Pennsylvania's Weatherization Priority List. Prepared by W Zalis, Energetics; Culp, Birch Point Consulting; C Kohler, LBNL; and PM LaFrance, U.S. Department of Energy; for the Pennsylvania Department of Community and Economic Development,, Columbia, Maryland. 


\section{Appendix A}

\section{Installation Process for Low-E Exterior Storm Windows}

Installation of exterior low-e storm windows is a relatively easy home improvement project that can be accomplished by most homeowners who are handy with a screw-driver or power drill and caulk. Unlike primary window replacement, construction experience or expertise is not required for a successful installation. See Figure A.1 for reference. The important elements of a successful low-e storm window installation include the following:

1. Positioning the storm window in the opening to check for a proper fit and orientation. For an "overlap" or "outside mount" installation, the storm window should completely cover the window and overlap the window trim on the top and sides of the window opening and the bottom expander should be flush against the sill. For a "blind stop" or "inside mount" installation, the storm window is installed in the same way, but sized to fit inside the overall window opening (for instance, mounting onto the wood jamb inside of surrounding masonry).

2. Caulking and securing the window in place: When the proper fit is confirmed, the surface on which the storm window will be mounted should be caulked to decrease air leakage and the storm window should be screwed in place. Note, the bottom expander ${ }^{1}$ should not be caulked or screwed to the bottom sill to allow proper drainage through the weep holes ${ }^{2}$.

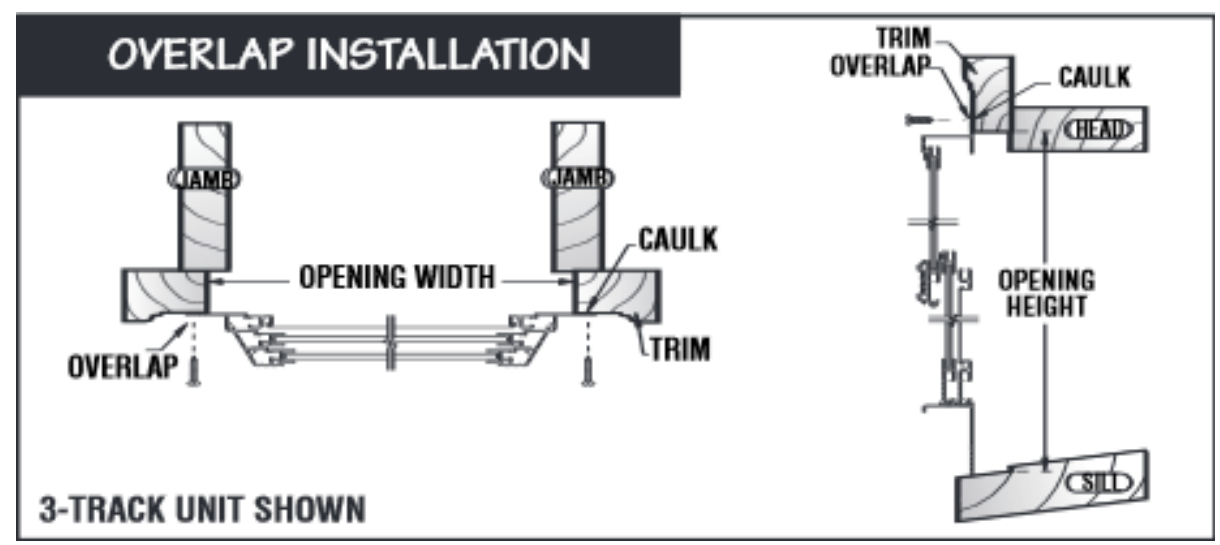

Figure A.1. Top View Horizontal (left) and Side View Vertical (right) Section of an Exterior Storm Window

\footnotetext{
${ }^{1}$ Typical storm windows will come with a window sill expander, which is a device that allows the bottom of the storm window to expand (around $1 / 2$ inch) to meet the angled sill of the window opening.

${ }^{2}$ In typical installation, the bottom edge of an exterior storm window is left unsealed and contains weep holes to provide drainage for any water that accumulates between the storm and primary window to prevent mold growth and water damage.
} 


\section{Appendix B}

\section{Installation Process for Low-E Interior Storm Windows}

Installation of interior low-e storm windows is also a relatively easy home improvement project that can be accomplished by most homeowners who are handy with a screw-driver or power drill. Typically caulk is only needed to fill in gaps caused by out of square window frames. Unlike primary window replacement, construction experience or expertise is not required for a successful installation. The important elements of a successful interior low-e storm panel installation include the following:

1. The interior panel is placed into the main window opening and installed against a blind stop. The blind stop prevents the interior panel from being pressed against the primary window and also acts as a thermal break between the panel frame and primary window frame. If a window frame does not have an existing blind stop, one must be put in place

2. The panel is then secured to the frame by mounting screws through the center of the mainframe, as shown in Figure B.1. It is very important that the panel is installed square to ensure proper sealing and operation and that the screws are not over-tightened as this will cause the seal on the opposite side to pull away.

3. Once the panel is in place, the edges are checked for gaps between the seal and door frame. Any gaps should be filled with caulk to complete the seal.

4. A trim stop can also be installed to secure the interior panel in place and cover the seal from view. The trim is mainly aesthetic and can be finished to match the color and texture of the existing jamb. This was not installed in the Lab Homes experiment, as it does not affect the energy performance of the low-e storm window.

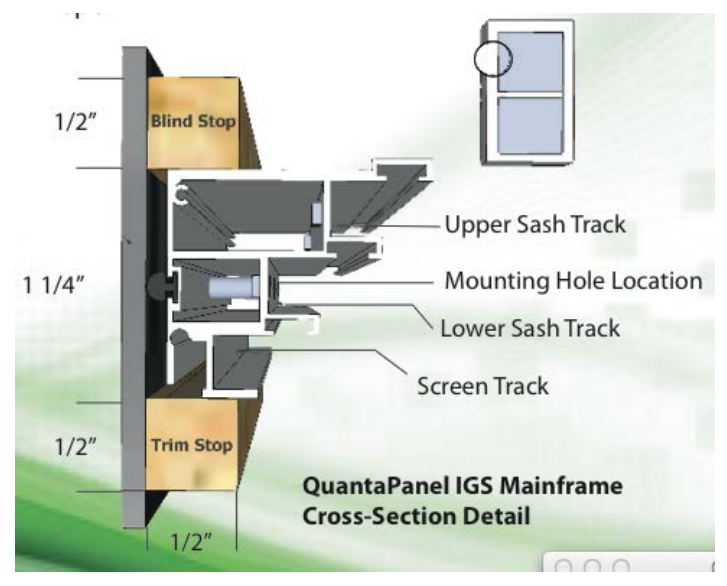

Figure B.1. Cross-Section of QuantaPanel Interior Panel 


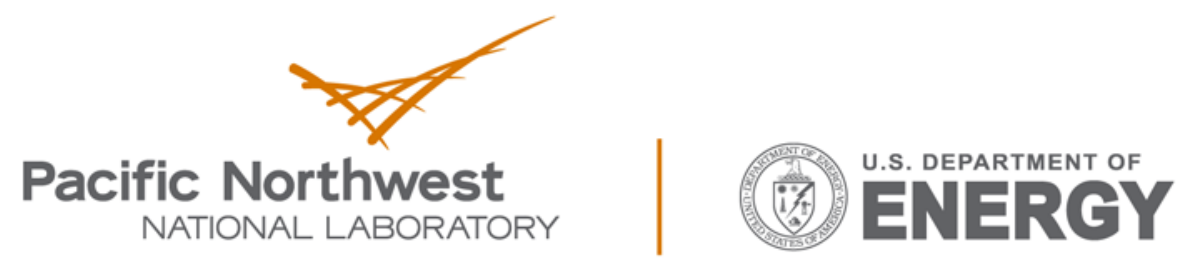

Proudly Operated by Battelle Since 1965

902 Battelle Boulevard

P.O. Box 999

Richland, WA 99352

1-888-375-PNNL (7665)

www.pnnl.gov 